Article

\title{
Bimetallic Pd-Au/SiO 2 Catalysts for Reduction of Furfural in Water
}

\author{
Magdalena Modelska ${ }^{1}$, Michal J. Binczarski ${ }^{1}$, Zbigniew Kaminski ${ }^{1}{ }^{\circledR}$, Stanislaw Karski ${ }^{1}$, \\ Beata Kolesinska $^{2}\left(\mathbb{D}\right.$, Pawel Mierczynski ${ }^{1}\left(\mathbb{D}\right.$, Courtney J. Severino ${ }^{3}$, Andrei Stanishevsky ${ }^{3}$ and \\ Izabela A. Witonska 1,*(D)
}

1 Institute of General and Ecological Chemistry, Lodz University of Technology, 116 Zeromskiego Street, 90-924 Lodz, Poland; modelska.magdalena89@gmail.com (M.M.); michal.binczarski@p.lodz.pl (M.J.B.); zbigniew.kaminski@p.lodz.pl (Z.K.); stanislaw.karski@p.lodz.pl (S.K.); pawel.mierczynski@p.lodz.pl (P.M.)

2 Institute of Organic Chemistry, Lodz University of Technology, 116 Zeromskiego Street, 90-924 Lodz, Poland; beata.kolesinska@p.lodz.pl

3 Department of Physics, University of Alabama at Birmingham, 1300 University Blvd., Birmingham, AL 35233, USA; cosev@uab.edu (C.J.S.); astan@uab.edu (A.S.)

* Correspondence: izabela.witonska@p.lodz.pl; Tel.: +48-42-631-30-94

Received: 15 March 2020; Accepted: 16 April 2020; Published: 20 April 2020

\begin{abstract}
Catalytic systems based on bimetallic $\mathrm{Pd}-\mathrm{Au}$ particles deposited on $\mathrm{SiO}_{2}$ were prepared by ultrasonically assisted water impregnation and used in the hydrogenation of furfural obtained by the acidic hydrolysis of waste biomass (brewery's spent grain) in aqueous phase. $\mathrm{Pd}-\mathrm{Au} / \mathrm{SiO} 2$ catalysts containing $50 \mathrm{~g}$ of $\mathrm{Pd}$ and 2-100 $\mathrm{g}$ of Au per $1 \mathrm{~kg}$ of catalyst were characterized by high activity in the studied process and, depending on the $\mathrm{Pd} / \mathrm{Au}$ ratio, selectivity to 2-methyloxolan-2-ol. The modification of $5 \% \mathrm{Pd} / \mathrm{SiO}_{2}$ by $\mathrm{Au}$ leads to the formation of dispersed $\mathrm{Au}-\mathrm{Pd}$ solid solution phases, which was confirmed by XRD, XPS, ToF-SIMS, SEM-EDS, and $\mathrm{H}_{2}$-TPR techniques. The effect of dilution of surface palladium by gold atoms is probably crucial for modification of the reaction mechanism and formation of 2-methyloxolan-2-ol as the main product.
\end{abstract}

Keywords: acidic hydrolysis of waste biomass; furfural hydrogenation in aqueous phase; $\mathrm{Pd}-\mathrm{Au} / \mathrm{SiO}{ }_{2}$; interaction $\mathrm{Pd}$ and $\mathrm{Au}$; Pd-Au solid solution

\section{Introduction}

Lignocellulosic biomass is a very interesting chemical raw material, which is a renewable and easily available source of cellulose (30-45\%), hemicellulose (20-35\%), and lignin (10-20\%). Currently, biomass is mainly used as fuel to obtain energy, especially heat, but its chemical treatment allows for the obtaining of many valuable products; e.g., furfural, levulinic acid, etc. Furfural is prepared by acid hydrolysis of pentoses that are produced during the process of depolymerization of hemicellulose [1-3], but the exact mechanism of its formation is not fully understood. In the literature, several alternative synthetic pathways can be found [3-8]. According to the most cited mechanism, the 1,2-ethanediol is formed from pentoses and is further converted to furfural in the presence of protons derived from an acidic catalyst [3]. In other works, furfural is formed in an acidic medium through an acyclic dehydration of pentoses [4-8]. Nimlos et al. [7] attempted to determine the energy levels of transition states for the specified mechanisms through quantum modeling. Their studies have shown that, in energy terms, intramolecular rearrangement is more beneficial than opening a sugar ring. On the other hand, Shafizadeh et al. [8] investigated the pyrolysis products of xylan, among which they found furfural formed during decomposition of glycosidic groups of this polysaccharide. Antal et al. [9] undertook the analysis of two hypotheses, the first concerned ring opening and the second related 
to pyranose rearrangement mechanisms. Based on the kinetic studies, the authors showed that the model used for the cyclic dehydration mechanism coincides with the results of the tests. Regardless of the mechanism of furfural formation, this valuable platform compound can be easily produced by biomass acid hydrolysis.

Currently, China is the main furfural producer (over $80 \%$ of global production) and the main furfural consumer (over $72 \%$ of the world consumption) [10]. The production of furfural on an industrial scale is dominated by technology developed in 1922 by the Quaker Oats Company and described in Patent US1735084A. The method requires the use of concentrated mineral acids $\left(\mathrm{H}_{2} \mathrm{SO}_{4}\right.$ or $\mathrm{HCl})$ as catalysts and produces the furfural with efficiency reaching up to $50 \%$ of the theoretical yield. The use of acids facilitates access to the densely packed lignocellulosic structure. Currently, scientists are developing alternative technologies based on zeolites (e.g., MCM-41 Mobil Composition of Matter No. 41) or the hydrated choline chloride-citric acid system, but all reported research results in this area were obtained using commercial xylose as a substitute of biomass [11-17].

The advantages of lignocellulosic biomass processing to furfural are a high price of this product and the fact that it can be further transformed into a broad range of valuable chemicals with important and diversified commercial applications [18]. Furfural plays an increasingly important role as one of the key compounds produced in the so-called lignocellulose biorefinery. It can be a substrate for manufacturing over 80 chemicals. The furfural derivatives used as propellant components include: 2-methyl tetrahydrofuran (MTHF), ethyl furfuryl ether (EFE), 2-methyl furan (MF), tetrahydrofurfuryl alcohol (THFA), furfuryl acetate, and glycerol acetals [19].

Hydrogenolysis of furfural $\mathrm{CH}=\mathrm{O}$ bonds yields 2-methylfuran, which, after further reduction, may be converted to 2-methyltetrahydrofuran. In turn, the milder hydrogenation of the furfural aldehyde group produces furfuryl alcohol (FA), which is the most popular chemical obtained from furfural. Over $60 \%$ of the annual production of furfural is converted to this product. A typical way of obtaining furfuryl alcohol is the reduction of furfural in the gas phase, catalyzed by $\mathrm{Cu}$-based systems, typically copper chromite. FA is used in the production of foundry resins, by crosslinking furfuryl alcohol, sometimes in combination with other compounds such as furfural, formaldehyde, phenolic compounds, and urea. Such resins have very good chemical, mechanical, and thermal properties. Their characteristic features are high corrosion and solvent resistances [3,19].

Furfuryl alcohol may be etherified with ethanol, resulting in ethyl furfuryl ether (EFE). The production and use of this compound as clean fuel has been patented by Shell [20]. Van Buijtenen also obtained a patent [21] describing the process of obtaining diesel fuel and kerosene. The process involves the formation of a mixture of intermediate oligomers resulting from the combination of furfuryl alcohol molecules linked with C-C bonds. The oligomers temporarily formed are finally hydrogenated to a $\mathrm{C}_{9}-\mathrm{C}_{20}$ hydrocarbon mixture in the final product.

Further hydrogenation of double bonds in the furan ring leads to tetrahydrofurfuryl alcohol (THFA). In industry, this process is carried out in two stages. During the first stage, furfural is reduced to FA, which is then converted to THFA in another reaction during the second stage. Nickel-based catalytic systems [22-25] are the most used in both the one- and two-stage process of THFA manufacturing. Other catalysts tested to obtain THFA contain Pt, Pd, and Ru [26-30]. Tetrahydrofurfuryl alcohol is known primarily as a "green" solvent used in agriculture, industrial printing inks, and cleaning products for electronics. This alcohol has also been successfully tested as a fuel additive to improve the mixing of ethanol with diesel, which results in a cleaner fuel. The possibility of using THFA as a fuel results from its relatively high octane number $(\mathrm{ON}=83)$ as well as its physical and chemical similarity to kerosene. Moreover, the products of THFA etherification can be used as diesel fuel additives, reducing emissions of solid particles [3,19,28,31-34].

Another interesting product of furfural reduction is a pair of tautomers: 5-hydroxy-2-pentanone and 2-methyloxolan-2-ol. These compounds occur naturally in the environment, for example in the Trametes versicolor mushrooms, and probably have antioxidant/anti-inflammatory activities [33]. These expensive intermediates are used in the synthesis of amino acids, fragrances, pharmaceuticals, 
polymers, and they can be prepared by catalytic furfural reduction in the aqueous phase [34]. It is known that ketones, like 5-hydroxy-2-pentanone, can react either as the straight-chain form or as the cyclic hemiketal (2-methyloxolan-2-ol), and an equilibrium between these forms has been assumed.

Current research on the reduction of furfural in liquid phase focuses on the search for environmentally friendly, selective catalytic systems. Replacing traditional, chromium-based, copper chromite catalysts in furfural reduction is problematic due to the low selectivity of transition metal-based systems towards this compound. Previous research revealed a high potential of modified palladium catalysts in the discussed reaction [28,35-38]. Recent publications indicate the possibility of using Au-modified palladium systems in furfural hydrogenation $[39,40]$.

In this paper, the activity and selectivity of palladium catalysts, supported on $\mathrm{SiO}_{2}$ and modified with gold in aqueous phase, were studied in the reduction of furfural into valuable chemicals, like furfuryl alcohol, tetrahydrofurfuryl alcohol, 5-hydroxy-2-pentanone, and 2-methyloxolan-2-ol. The direction of the hydrogenation of furfural in the aqueous phase on palladium catalysts depends on many factors, including the size of the crystallites and the interactions of palladium with a metallic promoter or support [41]. Modification of palladium catalysts with second metals, e.g., gold, can lead to the formation of an active phase with unique catalytic properties in a given process, e.g., unexpectedly high selectivity for one product or the creation of new products. It is known that palladium interacts with metals in various ways, for example with bismuth and thallium, it creates intermetallic compounds with defined stoichiometry, which are active centers of a new type and significantly modify the catalytic properties of such systems in oxidation, reduction, or hydrodechlorination reactions. Silver and copper, on the other hand, create solid solutions with palladium in a wide range of molar ratios of both metals, which particularly affects the course of structurally sensitive reactions occurring on active centers composed of a certain number of atoms of a given metal. This publication presents the results of a study on the type of interaction between palladium and gold on the silica surface and assessment of their effect on catalytic properties in the reaction of furfural reduction in water. The crystallite size and phase composition of bimetallic palladium-gold supported on silica systems and their effect on the catalysts performance were investigated using a variety of techniques.

\section{Results}

Based on the available literature on the reduction of furfural in the water solution over palladium catalysts, a list of main reaction products was prepared (Scheme 1). This scheme may help to understand the path of furfural reduction over gold-modified palladium catalysts supported on $\mathrm{SiO}_{2}$ in water.

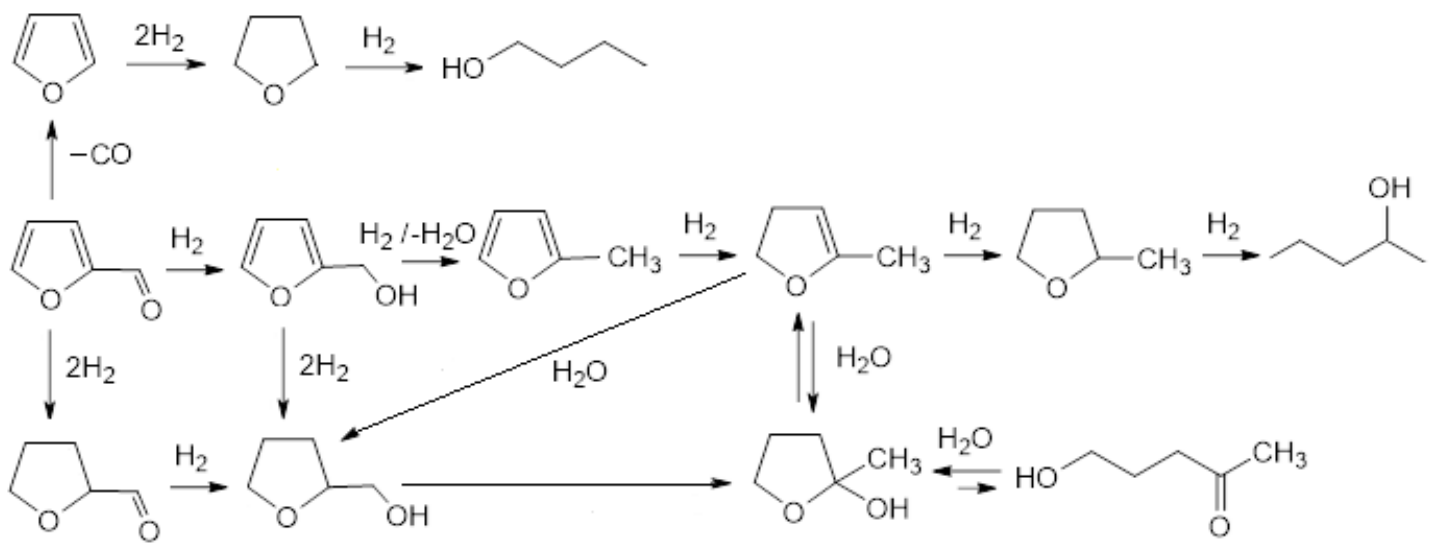

Scheme 1. The main products of furfural reduction over Pd/support systems in water phase on the base of literature data [35-41]. 
Catalytic results are expressed as a conversion degree $(X, \%)$ and selectivity for individual products $\left(\mathrm{S}_{\text {Product }} \%\right)$. Those parameters were defined as:

$$
\begin{gathered}
\mathrm{X}=\left[1-\left(\mathrm{C}_{\text {Furfura }} / \mathrm{C}_{0 \text { Furfural }}\right)\right] \times 100 \% ; \\
\mathrm{S}_{\text {Product }}=\left[\mathrm{C}_{\text {Product }} /\left(\mathrm{C}_{0 \text { Furfural }}-\mathrm{C}_{\text {Furfural }}\right)\right] \times 100 \%
\end{gathered}
$$

where: $C_{0}$ Furfural is a molar concentration of furfural at the beginning of the reduction process, $\mathrm{C}_{\text {Furfural }}$ is a molar concentration of furfural after time $t, C_{\text {Product }}$ is a molar concentration of the product, which includes: furfuryl alcohol, 2-methyl-4,5-dihydrofuran, tetrahydrofurfuryl alcohol, and 2-methyloxolan-2-ol.

An addition of gold to monometallic palladium catalyst $5 \% \mathrm{Pd} / \mathrm{SiO}_{2}$ substantially changes selectivity in the reaction of furfural reduction into individual products (Table 1). The main products in the reaction of furfural reduction in water are tetrahydrofurfuryl alcohol or mixture of tautomers 2-methyloxolan-2-ol and 5-hydroxy-2-pentanone depending on the composition of bimetallic catalysts. Bimetallic catalysts containing $5 \mathrm{wt}-\% \mathrm{Pd}$ and $1 \mathrm{wt}-\% \mathrm{Au}$ are characterized by the highest selectivity to 2-methyloxolan-2-ol and 5-hydroxy-2-pentanone among all bimetallic systems with lower and higher $\mathrm{wt}-\%$ of gold. Bimetallic systems containing more than $1 \mathrm{wt}-\%$ of gold in their composition work more selectively towards tetrahydrofurfuryl alcohol.

Table 1. Conversion degree of furfural $(\mathrm{X}, \%)$ and selectivity to all products (furfuryl alcohol, 2-methyl-4,5-dihydrofuran, tetrahydrofurfuryl alcohol, and 2-methyloxolan-2-ol) after $2 \mathrm{~h}$ of furfural

\begin{tabular}{|c|c|c|c|c|c|c|}
\hline Catalyst & $\begin{array}{c}X \\
{[\%]}\end{array}$ & $\begin{array}{c}S_{\text {Furfuryl }} \\
\text { Alcohol }[\%]\end{array}$ & $\begin{array}{l}S_{\text {2-Methyl-4,5- }} \\
\text { Dihydrofuran }[\%]\end{array}$ & $\begin{array}{c}\mathbf{S}_{\text {Tetrahydrofurfuryl }} \\
\text { Alcohol }[\%]\end{array}$ & $\begin{array}{l}S_{\text {2-Methyloxolan- }} \\
\text { 2-ol +5-Hydroxy- } \\
\text { 2-Pentanone [\%] }\end{array}$ & $\begin{array}{c}\text { S Other } \\
\text { Products [\%] }\end{array}$ \\
\hline $5 \% \mathrm{Pd}-0.2 \% \mathrm{Au} / \mathrm{SiO}_{2}$ & 100 & 47.3 & - & 44.5 & - & 8.2 \\
\hline $5 \% \mathrm{Pd}-0.5 \% \mathrm{Au} / \mathrm{SiO}_{2}$ & 100 & 0.0 & 1.1 & 11.6 & 81.3 & 6.0 \\
\hline $5 \% \mathrm{Pd}-5 \% \mathrm{Au} / \mathrm{SiO}_{2}$ & 100 & 4.1 & 25.3 & 60.2 & - & 6.4 \\
\hline $5 \% \mathrm{Pd}-10 \% \mathrm{Au} / \mathrm{SiO}_{2}$ & 100 & 4.1 & 13.6 & 72.6 & - & 0.6 \\
\hline$* 5 \% \mathrm{Pd}-1 \% \mathrm{Au} / \mathrm{SiO}_{2}$ & $* 98$ & * 1.2 & $* 4.2$ & $* 5.4$ & * 85.2 & $* 4.0$ \\
\hline$* 5 \% \mathrm{Pd}-2 \% \mathrm{Au} / \mathrm{SiO}_{2}$ & * 94 & * 3.9 & * 28.6 & * 18.2 & * 46.2 & $* 3.1$ \\
\hline
\end{tabular}
hydrogenation in water over $\mathrm{Pd}-\mathrm{Au} / \mathrm{SiO}_{2}$ catalysts.

Reaction conditions: $\mathrm{T}=90^{\circ} \mathrm{C}, \mathrm{p}_{\mathrm{H} 2}=20 \mathrm{bar}, \mathrm{m}_{\mathrm{cat}}=0.5 \mathrm{~g}, \mathrm{C}_{0}$ Furfural $=0.1 \mathrm{M}, \mathrm{V}_{\text {Furfural }}=25 \mathrm{~mL}, \mathrm{t}=2 \mathrm{~h}$; Catalysts after drying in air at $110{ }^{\circ} \mathrm{C}, 6 \mathrm{~h}$ were reduced in $\mathrm{H}_{2}$ at $300{ }^{\circ} \mathrm{C}, 2 \mathrm{~h}$. ${ }^{*}$ Conversion degree of furfural obtained from brewery's spent grain $(\mathrm{X}, \%)$ and selectivity to all products over $5 \% \mathrm{Pd}-1 \% \mathrm{Au} / \mathrm{SiO}_{2}$ and $5 \% \mathrm{Pd}-2 \% \mathrm{Au} / \mathrm{SiO} 2 \mathrm{catalysts}$.

Under analogous conditions of hydrogen pressure and temperature, a hydrogenation of the furfural solution in water obtained from the brewery's spent grain was performed. For this purpose, the catalysts were selected because they presented the best catalytic properties among the tested catalytic systems in the reduction reaction of commercial furfural. The solution obtained from the brewing industry waste biomass was characterized by the presence of trace amounts of acetone and 2-butanone. The reduction of bio-furfural in aqueous solution on $5 \% \mathrm{Pd}-1 \% \mathrm{Au} / \mathrm{SiO}_{2}$ and $5 \% \mathrm{Pd}-2 \%$ $\mathrm{Au} / \mathrm{SiO}_{2}$ catalysts led essentially to the same products that were observed with a solution of commercial furfural in water.

Hydrogenation of furfural in water phase may result in the various products, which may be formed by reduction of subsequent double bonds in the molecule, internal rearrangement of the molecule, or addition of water. It was found that the composition of the products changes during the reaction (Table 2, Figure 1). At the beginning of the reaction, the furfuryl alcohol and 2-metylo-4,5-dihydrofuran as main products are observed. These compounds transformed together during the longer contact with catalyst into tetrahydrofurfuryl alcohol and mixture of tautomers: 
2-methyloxolan-2-ol and 5-hydroxy-2-pentanone. Among the uncharacterized reaction products are, among the others, the systems with carbonyl groups (as demonstrated by NMR analysis) and product adducts (e.g., dimers, as indicated by GC-MS analysis, Supplementary Materials).

Table 2. The influence of time on conversion degree of furfural $(\mathrm{X}, \%)$ and selectivity to all products (furfuryl alcohol, 2-methyl-4,5-dihydrofuran, tetrahydrofurfuryl alcohol, and 2-methyloxolan-2-ol) in the furfural reduction in water phase over $5 \% \mathrm{Pd}-1 \% \mathrm{Au} / \mathrm{SiO}_{2}$ catalyst.

\begin{tabular}{ccccccc}
\hline $\begin{array}{c}\text { Reaction } \\
\text { Time [h] }\end{array}$ & $\mathbf{X}[\%]$ & $\begin{array}{c}\mathbf{S}_{\text {Furfuryl }} \\
\text { Alcohol }[\%]\end{array}$ & $\begin{array}{c}\mathbf{S}_{\text {2-Methyl-4,5- }} \\
\text { Dihydrofuran }[\%]\end{array}$ & $\begin{array}{c}\mathbf{S}_{\text {Tetrahydrofurfuryl }} \\
\text { Alcohol }[\%]\end{array}$ & $\begin{array}{c}\mathbf{S}_{\text {2-Methyloxolan- }} \\
\text { 2-ol+5-Hydroxy- } \\
\text { 2-Pentanone }[\%]\end{array}$ & $\begin{array}{c}\mathbf{S}_{\text {Other }} \\
\text { Products }\end{array}$ \\
\hline 0.25 & 59.5 & 46.2 & 23.2 & 0 & 0 & 30.6 \\
0.5 & 75.6 & 12.7 & 10.3 & 42.1 & 30.3 & 6.6 \\
1 & 87.2 & 9.4 & 5.2 & 30.2 & 50.1 & 3.4 \\
2 & 100 & 0 & 1.8 & 0 & 96.5 & 1.7 \\
4 & 100 & 0 & 0 & 0 & 98.6 & 1.4 \\
\hline
\end{tabular}

Reaction conditions: $\mathrm{T}=90^{\circ} \mathrm{C}, \mathrm{p}_{\mathrm{H} 2}=20 \mathrm{bar}, \mathrm{m}_{\text {cat }}=0.5 \mathrm{~g}, \mathrm{C}_{0 \text { Furfural }}=0.1 \mathrm{M}, \mathrm{V}_{\text {Furfural }}=25 \mathrm{~mL}$; Catalysts after drying in air at $110^{\circ} \mathrm{C}, 6 \mathrm{~h}$ were reduced in $\mathrm{H}_{2}$ at $300^{\circ} \mathrm{C}, 2 \mathrm{~h}$.

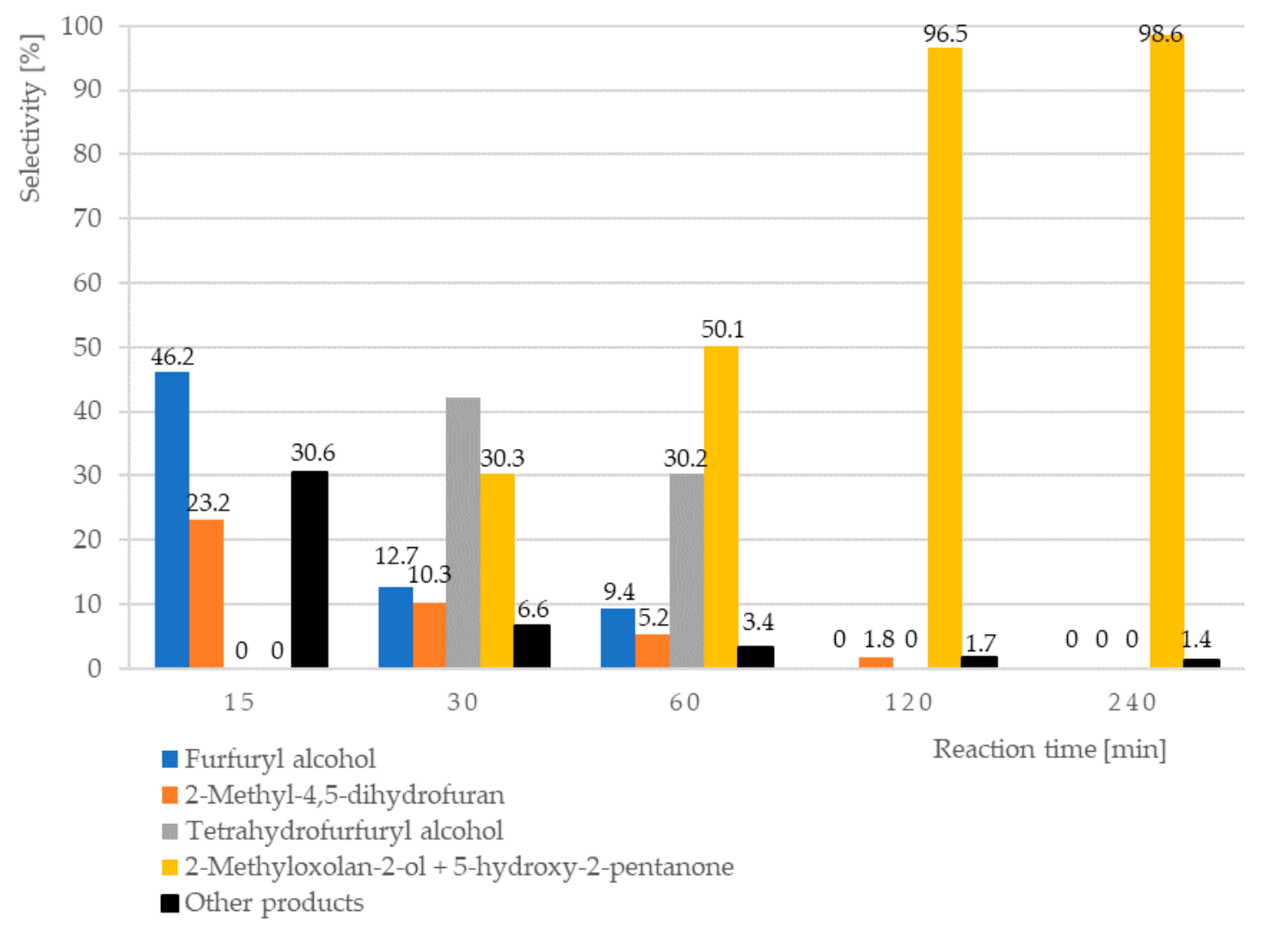

Figure 1. The influence of reaction time on selectivity into invidual products (furfuryl alcohol, 2-methyl4,5-dihydrofuran, tetrahydrofurfuryl alcohol, and 2-methyloxolan-2-ol + 5-hydroxy-2-pentanone) of the furfural reduction in water over $5 \% \mathrm{Pd}-1 \% \mathrm{Au} / \mathrm{SiO}_{2}$ catalyst. Reaction conditions: $\mathrm{T}=90^{\circ} \mathrm{C}, \mathrm{p}_{\mathrm{H} 2}=20 \mathrm{bar}$, $\mathrm{m}_{\text {cat }}=0.5 \mathrm{~g}, \mathrm{C}_{0 \text { Furfural }}=0.1 \mathrm{M}, \mathrm{V}_{\text {Furfural }}=25 \mathrm{~mL}$; Catalysts after drying in air at $110{ }^{\circ} \mathrm{C}, 6 \mathrm{~h}$ were reduced in $\mathrm{H}_{2}$ at $300{ }^{\circ} \mathrm{C}, 2 \mathrm{~h}$.

In order to understand the behavior of $\mathrm{Pd}-\mathrm{Au} / \mathrm{SiO}_{2}$ systems in the reduction of furfural in aqueous phase, the following studies x-ray diffraction (XRD), scanning electron microscopy and energy-dispersive $X$-ray spectroscopy (SEM-EDS), time-of-flight secondary ion mass spectroscopy (ToF-SIMS), X-ray photoelectron spectroscopy (XPS), and temperature programmed reduction (TPR) were conducted. 
Figure 2 presents XRD patterns of bimetallic catalysts: (1) $5 \% \mathrm{Pd} / \mathrm{SiO}_{2} ;(2) 5 \% \mathrm{Pd}-0.2 \% \mathrm{Au} / \mathrm{SiO}_{2}$; (3) $5 \% \mathrm{Pd}-0.5 \% \mathrm{Au} / \mathrm{SiO}_{2} ;$ (4) $5 \% \mathrm{Pd}-1 \% \mathrm{Au} / \mathrm{Si}_{\mathrm{O} 2} ;$ (5) $5 \% \mathrm{Pd}-2 \% \mathrm{Au} / \mathrm{SiO}_{2} ;$ (6) $5 \% \mathrm{Pd}-5 \% \mathrm{Au} / \mathrm{SiO}_{2}$; (7) $5 \% \mathrm{Au} / \mathrm{SiO}_{2}$. Before XRD examinations, the catalysts samples were reduced in hydrogen at $300^{\circ} \mathrm{C}$.

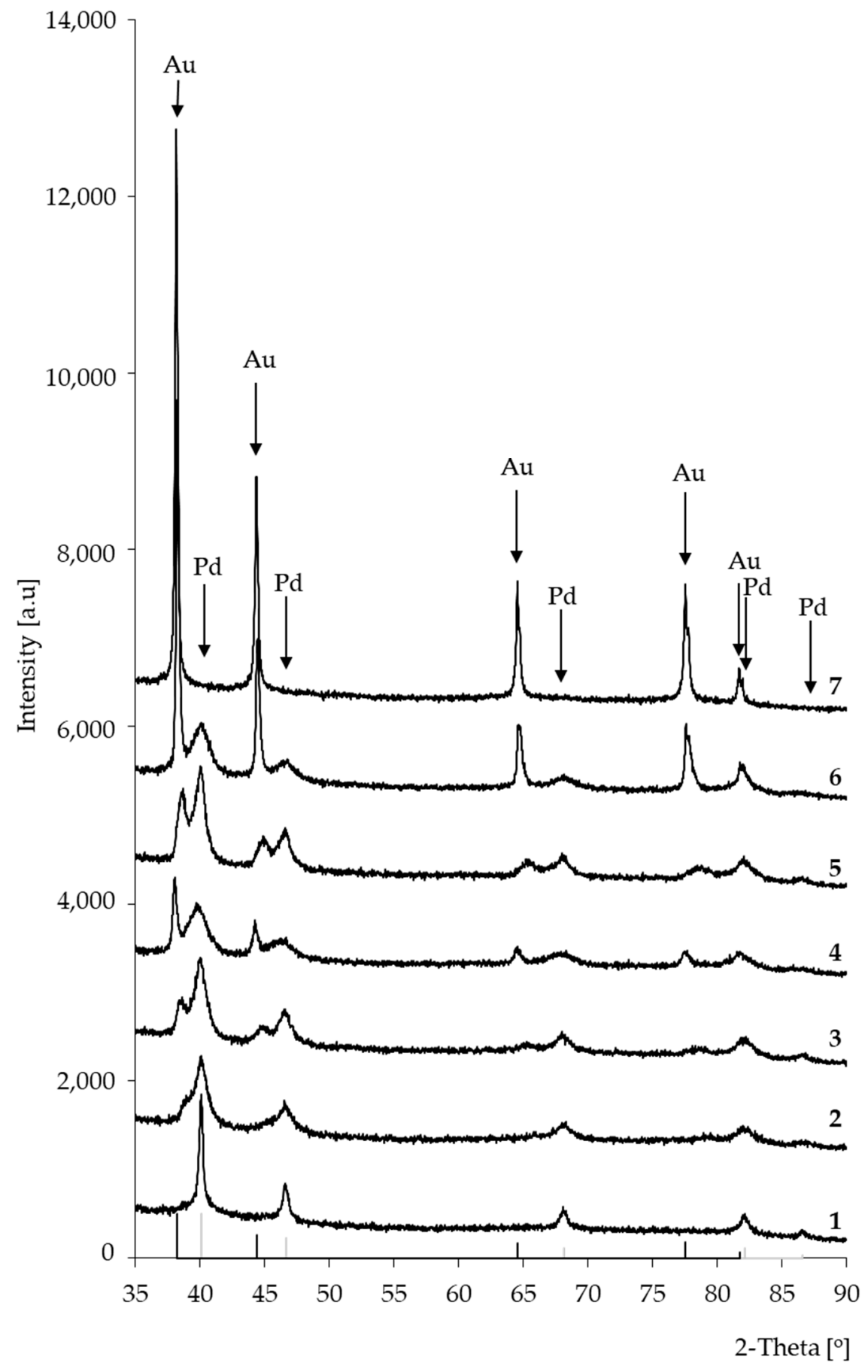

Figure 2. X-ray diffraction patterns of $\mathrm{Pd}-\mathrm{Au} / \mathrm{SiO}_{2}$ : (1) $5 \% \mathrm{Pd} / \mathrm{SiO}_{2} ;$ (2) $5 \% \mathrm{Pd}-0.2 \% \mathrm{Au} / \mathrm{SiO}_{2}$; (3) $5 \% \mathrm{Pd}-0.5 \% \mathrm{Au} / \mathrm{SiO}_{2}$; (4) $5 \% \mathrm{Pd}-1 \% \mathrm{Au} / \mathrm{SiO}_{2}$; (5) $5 \% \mathrm{Pd}-2 \% \mathrm{Au} / \mathrm{SiO}_{2}$; (6) $5 \% \mathrm{Pd}-5 \% \mathrm{Au} / \mathrm{SiO}_{2}$; (7) $5 \% \mathrm{Au} / \mathrm{SiO}_{2}$. Bimetallic catalysts were activated in hydrogen atmosphere for $2 \mathrm{~h}$ at $300{ }^{\circ} \mathrm{C}$.

In the case of all bimetallic $\mathrm{Pd}-\mathrm{Au} / \mathrm{SiO}_{2}(2-6)$ catalysts, the diffraction maxima attributed to metallic Pd nanocrystalline phase were observed. The introduction of gold into the system caused the formation of additional maxima on diffractograms (Figure 2). In the case of bimetallic systems $5 \% \mathrm{Pd}-5 \% \mathrm{Au} / \mathrm{SiO}_{2}$ 
(6), the positions of these maxima were very close to those of metallic gold (Figures 2 and 3) The observed changes in the peak positions on the diffractograms of the bimetallic $\mathrm{Pd}-\mathrm{Au} / \mathrm{SiO}_{2}$ catalysts can be indicative to the formation of solid solutions. The inset in Figure 3 displays the trend in $\mathrm{Pd}$ (111) plane spacing as a function of alloy composition in $\mathrm{Pd}-\mathrm{Au} / \mathrm{SiO}_{2}$ system (Vegard's rule). Such a trend indicates the solid solution formation in the $\mathrm{Pd}-\mathrm{Au} / \mathrm{SiO}_{2}$ systems during the activation step in a hydrogen atmosphere.

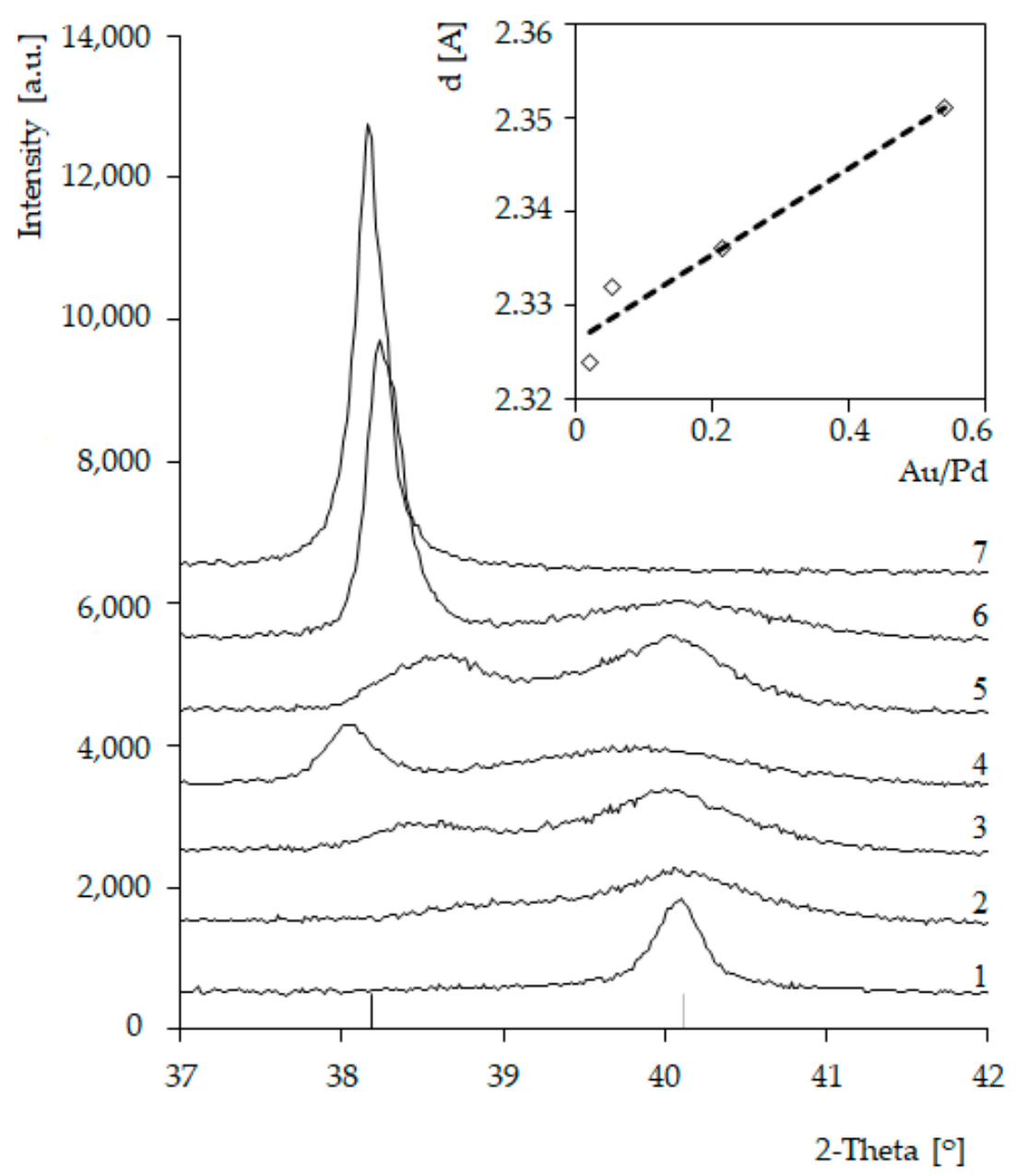

Figure 3. Diffractograms of catalysts: (1) $5 \% \mathrm{Pd} / \mathrm{SiO}_{2}$; (2) $5 \% \mathrm{Pd}-0.2 \% \mathrm{Au} / \mathrm{SiO}_{2}$; (3) $5 \% \mathrm{Pd}-0.5 \% \mathrm{Au} / \mathrm{SiO}_{2}$; (4) $5 \% \mathrm{Pd}-1 \% \mathrm{Au} / \mathrm{SiO}_{2}$; (5) $5 \% \mathrm{Pd}-2 \% \mathrm{Au} / \mathrm{SiO}_{2}$; (6) $5 \% \mathrm{Pd}-5 \% \mathrm{Au} / \mathrm{SiO}_{2} ;$; 7 ) $\% \mathrm{Au} / \mathrm{SiO}_{2}$ (activated in $\mathrm{H}_{2}$ for $2 \mathrm{~h}$ at $300{ }^{\circ} \mathrm{C}$ ) and linear relationship of plane distances as a function of those systems' composition (Vegard's rule).

The literature data also confirm the formation of $\mathrm{Pd}_{\mathrm{x}} \mathrm{Au}_{\mathrm{y}}$ solid solutions in the case of $\mathrm{Pd}-\mathrm{Au}$ catalysts supported on $\mathrm{SiO}_{2}, \mathrm{Al}_{2} \mathrm{O}_{3}, \mathrm{Fe}_{2} \mathrm{O}_{3}$, and amorphous aluminosilicate after their activation in oxidative atmosphere above $400{ }^{\circ} \mathrm{C}[42,43]$. However, the application of oxidative activation conditions for the catalysts tested in this study led to a decrease in the activity of $\mathrm{Pd}-\mathrm{Au} / \mathrm{SiO}_{2}$ systems. For this reason, the oxidation step was omitted in the preparation of bimetallic catalysts.

Furthermore, the addition of a higher amount of gold increased in intensity and narrowing of diffraction maxima attributed to the metallic gold. This can indicate that Au crystallites with the size apparently larger that $\mathrm{Pd}$ and $\mathrm{Au}-\mathrm{Pd}$ ones can be present on the surface of the bimetallic catalysts. The average sizes of palladium and gold crystallites in the studied catalytic systems were analyzed using the Scherrer equation, the results of which are summarized in Table 3. 
Table 3. Metal particle size of $\mathrm{Pd}-\mathrm{Au} / \mathrm{SiO}_{2}$ catalysts calculated on the basis of XRD studies according to the Scherrer equation.

\begin{tabular}{ccc}
\hline \multirow{2}{*}{ Catalysts } & \multicolumn{2}{c}{ Crystallite Size [nm] } \\
\cline { 2 - 3 } & $\mathbf{A u}$ & Pd \\
\hline $5 \% \mathrm{Pd} / \mathrm{SiO}_{2}$ & - & 21.3 \\
$5 \% \mathrm{Pd}-0.2 \% \mathrm{Au} / \mathrm{SiO}_{2}$ & - & 5.7 \\
$5 \% \mathrm{Pd}-0.5 \% \mathrm{Au} / \mathrm{SiO}_{2}$ & 15.1 & 7.7 \\
$5 \% \mathrm{Pd}-1 \% \mathrm{Au} / \mathrm{SiO}_{2}$ & 8.4 & 8.2 \\
$5 \% \mathrm{Pd}-2 \% \mathrm{Au} / \mathrm{SiO}_{2}$ & 24.4 & 5.6 \\
$5 \% \mathrm{Pd}-5 \% \mathrm{Au} / \mathrm{SiO}_{2}$ & 41.3 & 5.8 \\
$5 \% \mathrm{Au} / \mathrm{SiO}_{2}$ & 43.4 & - \\
\hline
\end{tabular}

On the basis of the results presented in Table 3 and literature data on the experiments with gold catalyzed furfural reduction $[39,40]$, it can be concluded that the dispersion of palladium is higher for bimetallic catalysts than for the monometallic $5 \% \mathrm{Pd} / \mathrm{SiO}_{2}$ system. The smallest Au crystallite size was determined for the bimetallic system containing $5 \% \mathrm{Pd}-1 \% \mathrm{Au} / \mathrm{SiO}_{2}$. It is generally recognized that catalytic properties of Au strongly depend on the size of the particle [44,45]. Better dispersion of palladium was crucial for higher activity and selectivity in the case of furfural reduction [41]. The literature data also indicates that the monometallic Au supported catalysts are catalytic active in various oxidation and reduction processes only when Au particles are smaller than $10 \mathrm{~nm}$ [46-49]. In the present study the calculation revealed the size of Au particle of $8.4 \mathrm{~nm}$ in the case of catalyst $5 \% \mathrm{Pd}-1 \% \mathrm{Au} / \mathrm{SiO}_{2}$. This system is characterized by a very good catalytic performance in furfural reduction (Table 1); therefore, it cannot be excluded that a small size of gold particles played a role in the enhancement of catalytic activity.

On the other hand, $\mathrm{Pd}-\mathrm{Au} / \mathrm{SiO}_{2}$ bimetallic catalysts containing more than $2 \% \mathrm{Au}$, despite much larger $\mathrm{Au}>10 \mathrm{~nm}$ crystallites, were also active in furfural reduction, but distribution of reaction products was different. For the $5 \% \mathrm{Pd}-10 \% \mathrm{Au} / \mathrm{SiO}_{2}$ catalyst, the main reaction product was tetrahydrofurfuryl alcohol, not 2-methyloxolan-2-ol (Table 1). However, it can be seen that regardless of the amount of gold introduced into the Pd-Au systems, the size of palladium crystallites calculated on the basis of the Scherrer equation is practically constant and ranges from 5.6 to $8.2 \mathrm{~nm}$. The size of palladium crystallites in bimetallic systems is much smaller than in an analogous monometallic $5 \% \mathrm{Pd} / \mathrm{SiO}_{2}$ catalyst (Table 3), and it may be the reason for changing the reaction path and creating new products (Table 1).

SEM-EDS analysis of selected catalyst samples revealed significant aggregation of metal seeded $\mathrm{SiO}_{2}$ particles and the rough surface morphology of the aggregates (Figure 4). It was also noted that the $\mathrm{Pd} / \mathrm{Au}$ molar weight ratios in $5 \% \mathrm{Pd}-1 \% \mathrm{Au} / \mathrm{SiO}_{2}$ and $5 \% \mathrm{Pd}-5 \% \mathrm{Au} / \mathrm{SiO}_{2}$ samples were higher than calculated (7.3/1.0 and $1.3 / 1.0$ vs 5.0/1.0 and 1.0/1.0, respectively). This could happen due to the competing formation of metal nanoparticles. It is possible that Au nanoparticles are formed competitively with alloy particles and grow faster. Such Au particles may have low adhesion to silica and may be lost during the process. 
A

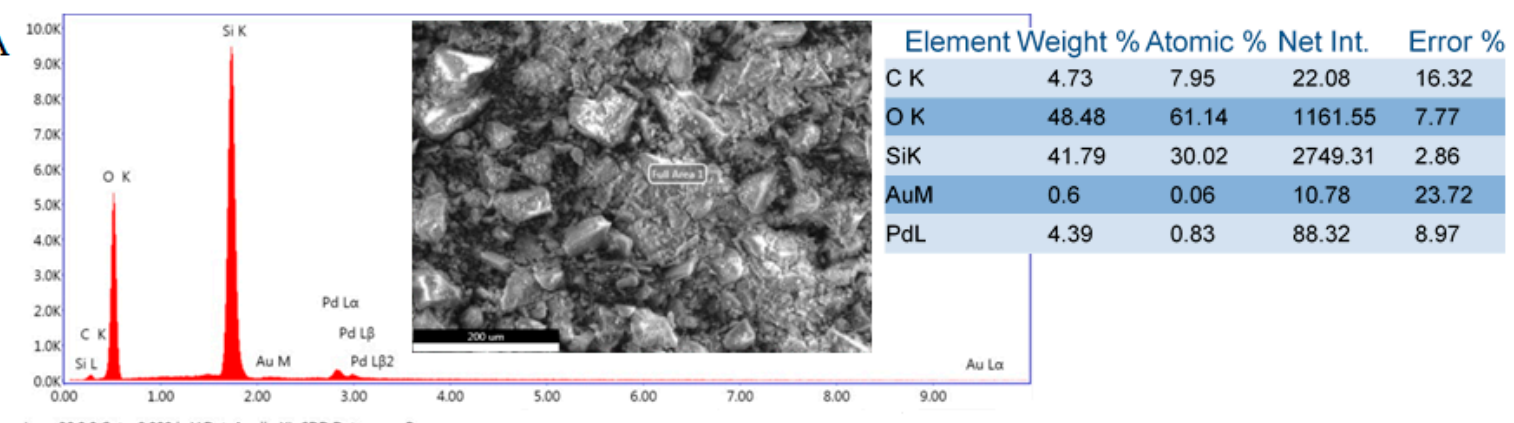

L Ssec 30.00 Cnts $0.000 \mathrm{keV}$ Det ADollo XL-SDD Det Reso

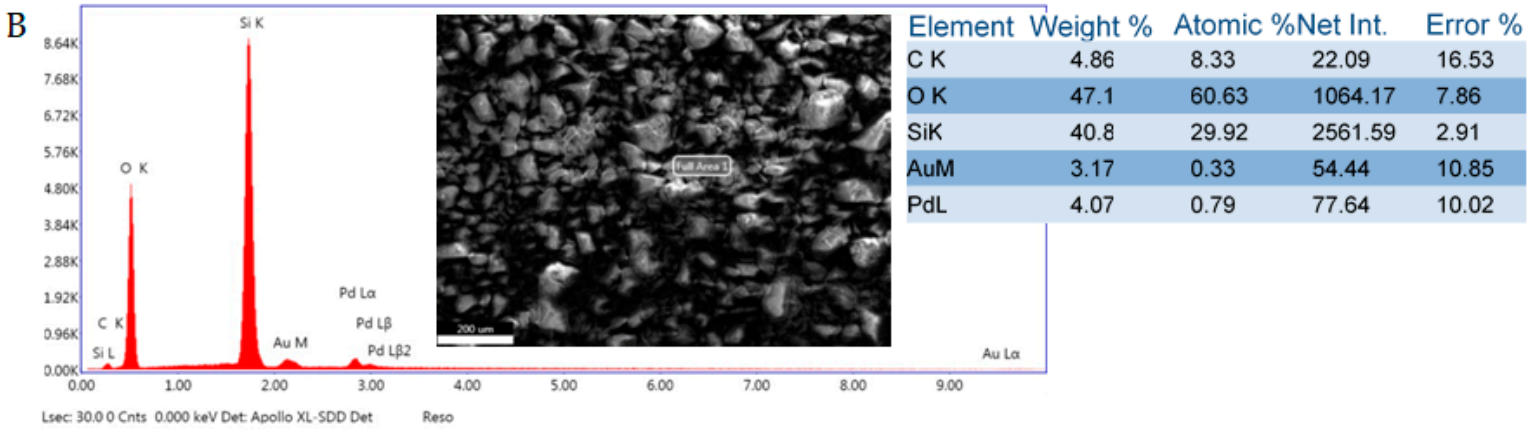

Figure 4. SEM-EDS surface composition analysis: (A) $-5 \% \mathrm{Pd}-1 \% \mathrm{Au} / \mathrm{SiO}_{2}$ catalyst; (B) $-5 \% \mathrm{Pd}-$ $5 \% \mathrm{Au} / \mathrm{SiO}_{2}$ catalyst.

The SEM-EDS elemental maps of catalysts containing $5 \% \mathrm{Pd} / \mathrm{SiO}_{2}, 5 \% \mathrm{Pd}-1 \% \mathrm{Au} / \mathrm{SiO}_{2}$, and $5 \% \mathrm{Pd}-$ $5 \% \mathrm{Au} / \mathrm{SiO}_{2}$ are presented in Figure 5.

(A)
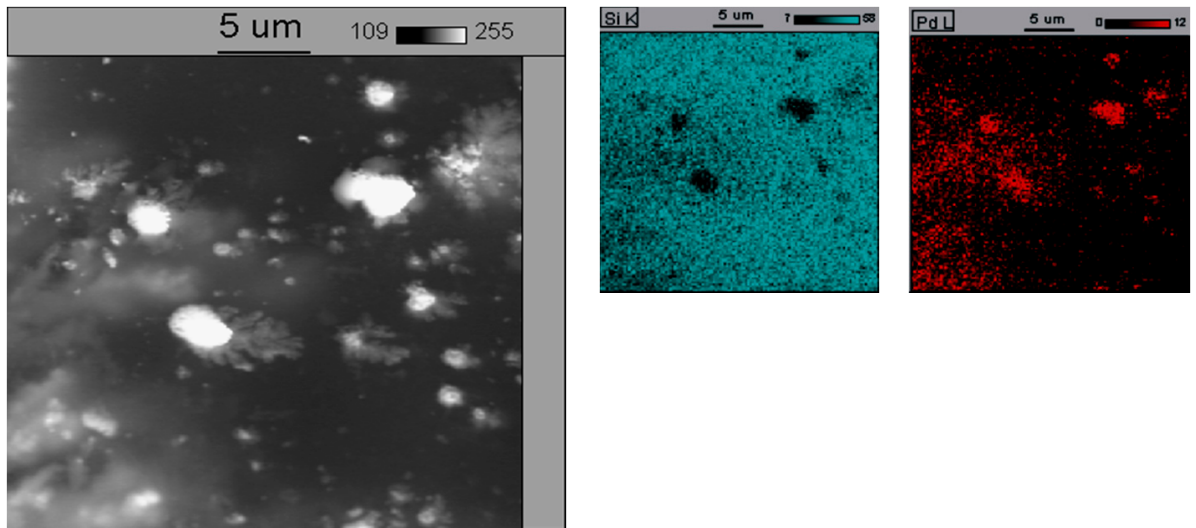

(B)
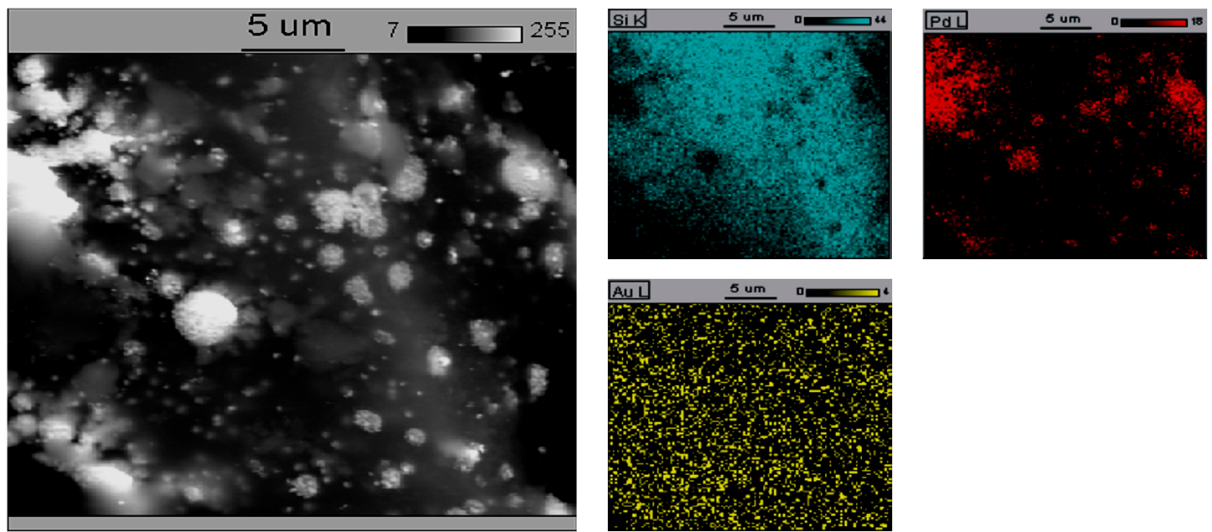

Figure 5. Cont. 
(C)

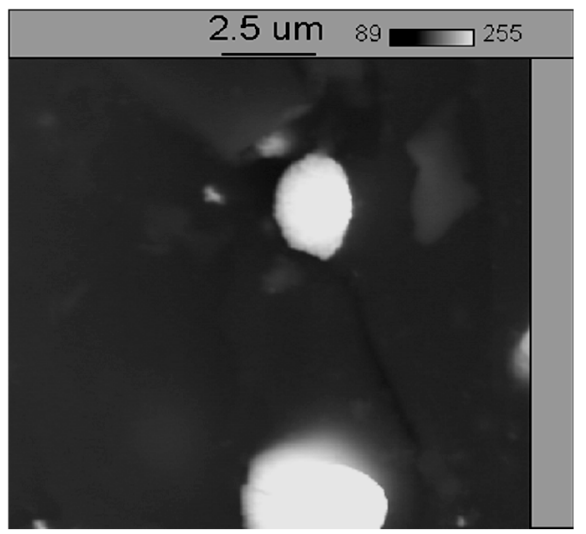

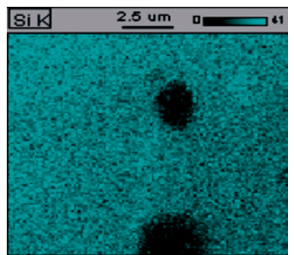
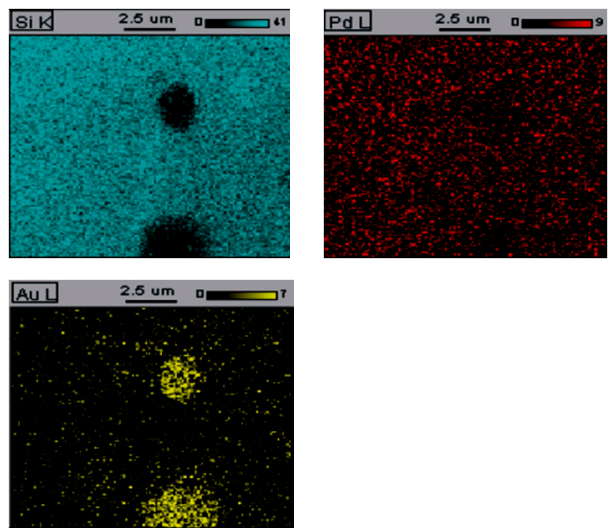

Figure 5. The back-scattered electron (BSE) photomicrograph of the (A) $-5 \% \mathrm{Pd} / \mathrm{SiO}_{2},(\mathbf{B})-5 \% \mathrm{Pd}-$ $1 \% \mathrm{Au} / \mathrm{SiO}_{2}$, and $(\mathrm{C})-5 \% \mathrm{Pd}-5 \% \mathrm{Au} / \mathrm{SiO}_{2}$ catalyst. The catalysts were previously reduced in $\mathrm{H}_{2}$ at $300{ }^{\circ} \mathrm{C}$ for $2 \mathrm{~h}$.

In the case of monometallic $5 \% \mathrm{Pd} / \mathrm{SiO}_{2}$ catalyst (Figure $5 \mathrm{~A}$ ), distinct conglomerations of variable size with a higher Pd content are observed. It indicates low homogeneity of this catalyst. The tendency of formation of large particles is likely the reason for low selectivity into 2-methyloxolan-2-ol in the reduction of furfural (Table 1). The introduction of small amounts of gold to palladium catalyst $\left(5 \% \mathrm{Pd}-1 \% \mathrm{Au} / \mathrm{SiO}_{2}\right.$, Figure $\left.5 \mathrm{~B}\right)$ causes better dispersion of palladium. Furthermore, the absence of gold-rich conglomerations on the surface is indicative to high homogeneity of gold in this system. These catalysts, characterized by relatively uniform distribution of gold and small crystallites of palladium, show higher selectivity for 2-methyloxolan-2-ol in the studied reaction.

Figure 6 shows the overlapped characteristic X-ray spectra of $5 \% \mathrm{Pd}-1 \% \mathrm{Au} / \mathrm{SiO}_{2}$ catalyst that were recorded at two points, $\mathrm{A}$ (moderately bright spot) and $\mathrm{B}$ (very bright spot). It supports the statement that small crystallites of gold are in intimate contact with palladium crystallites which indicates mutual interaction of palladium and gold. Those results are in good agreement with the XRD data.

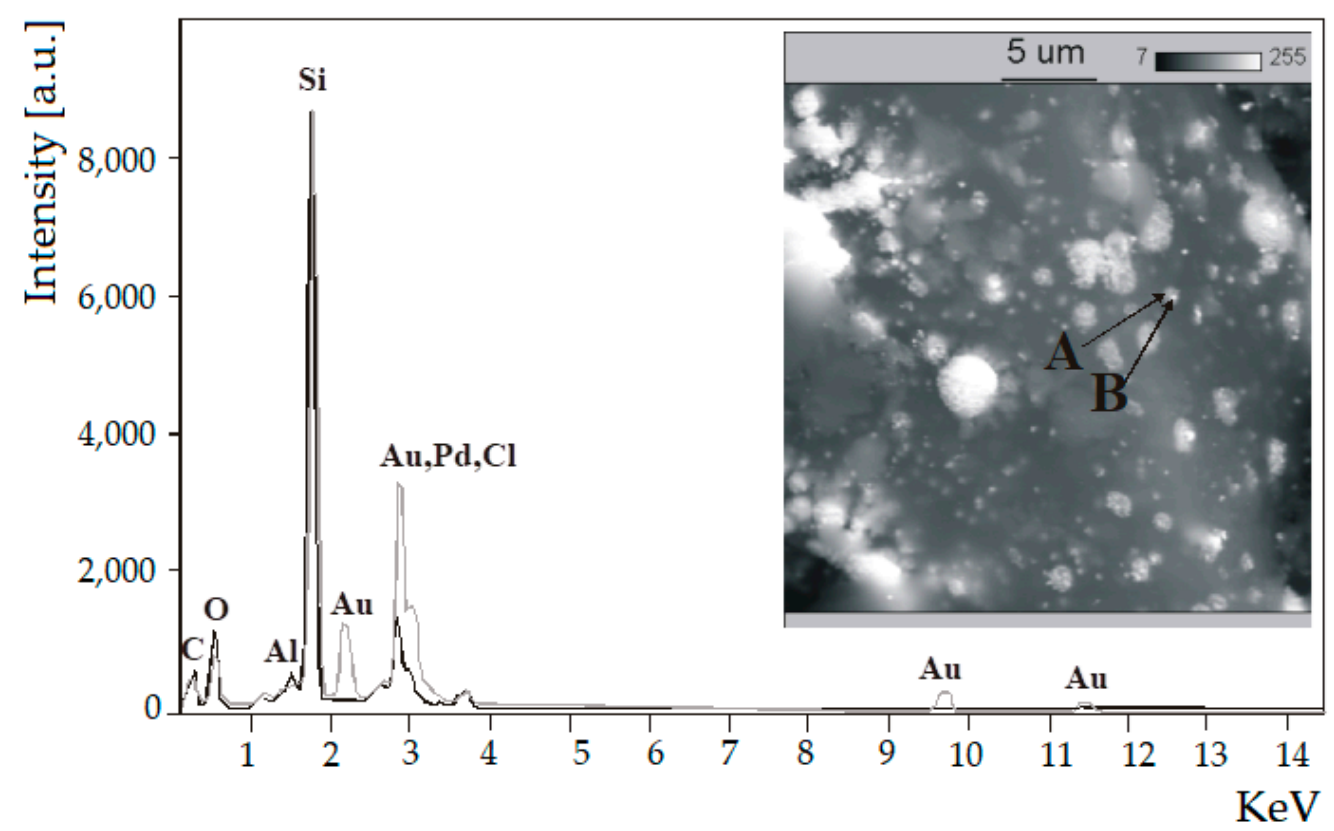

Figure 6. The back-scattered electron (BSE) photomicrograph and the characteristic X-ray spectra of fresh $5 \% \mathrm{Pd}-1 \% \mathrm{Au} / \mathrm{SiO}_{2}$ catalyst overlapped at point $\mathrm{A}$-And point $\mathrm{B}$ - The catalyst was previously reduced in $\mathrm{H}_{2}$ at $300{ }^{\circ} \mathrm{C}$ for $2 \mathrm{~h}$. 
The addition of increased amount of gold (5\%-wt. Au, Figure 5C) into palladium catalysts led to the formation of larger crystallites of gold-rich phase on the surface. The formation of relatively large gold crystallites and the surface of the $5 \% \mathrm{Pd}-5 \% \mathrm{Au} / \mathrm{SiO}_{2}$ catalyst enriched with $\mathrm{Au}$ atoms are probably the main reasons of poor selectivity into 2-methyloxolan-2-ol of this system in the process of furfural reduction in the aqueous phase (Table 1 ).

For a better understanding of the distribution pattern of $\mathrm{Au}$ and $\mathrm{Pd}$ atoms on the surface of silica, the samples of bimetallic catalysts were characterized by ToF-SIMS. This technique made it possible to observe the changes occurring on the catalyst surface which are invisible for XRD. Figure 7 shows secondary ion images of microareas of palladium catalyst supported on silica and modified with gold after reduction in hydrogen atmosphere for $2 \mathrm{~h}$ at $300^{\circ} \mathrm{C}$. The brightness of particular areas in the images corresponds to the intensity of secondary ion emission.

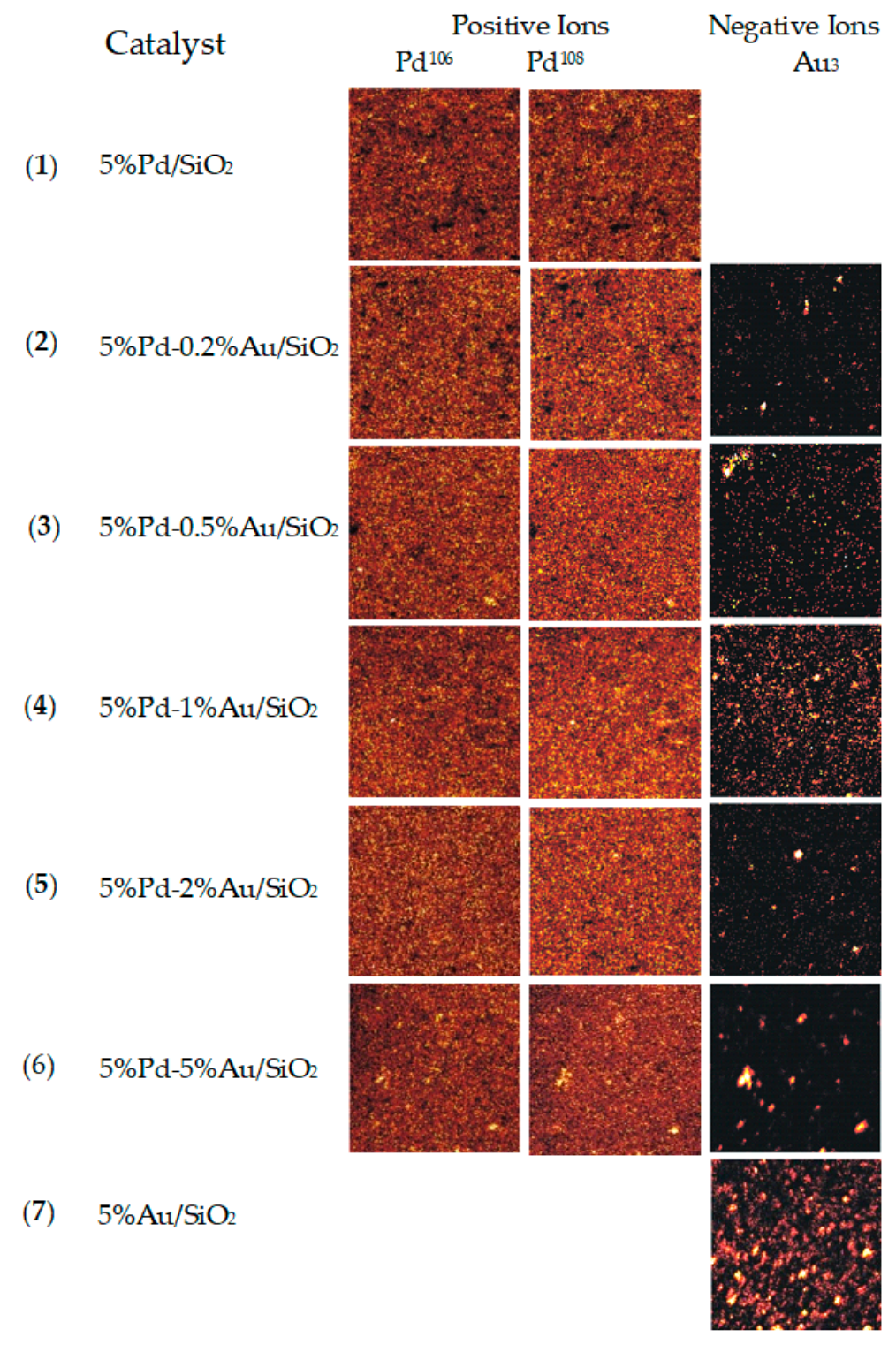

Figure 7. Secondary ions ToF-SIMS images of $\mathrm{Pd} / \mathrm{SiO}_{2}, \mathrm{Au} / \mathrm{SiO}_{2}$, and $\mathrm{Pd}-\mathrm{Au} / \mathrm{SiO}_{2}$ catalysts after reduction in $\mathrm{H}_{2}$ at $300{ }^{\circ} \mathrm{C}$. Images were recorded from $500 \times 500 \mu \mathrm{m}$ area with an extreme crossover working mode of primary $\mathrm{Ga}^{+}$gun. Spatial resolution of images set to $128 \times 128$ pixels.

The obtained images of bimetallic $\mathrm{Pd}-\mathrm{Au} / \mathrm{SiO}_{2}$ catalysts show inhomogeneous distribution of $\mathrm{Au}$ on the surface of silica (Table 4). Gold atoms tend to form regions of enhanced Au concentration 
which grow after incorporating greater amounts of gold into the systems. The best homogeneity of gold atoms on the surface was obtained for the catalyst $5 \% \mathrm{Pd}-1 \% \mathrm{Au} / \mathrm{SiO}_{2}$. Based on the received results, it was found that the distribution of $\mathrm{Pd}$ atoms is better in the case of bimetallic catalysts than monometallic $5 \% \mathrm{Pd} / \mathrm{SiO}_{2}$ system. The ToF-SIMS studies are in good agreement with XRD results.

Table 4. Amounts of $\mathrm{Au}_{3^{-}}$ions relative to ${ }^{106} \mathrm{Pd}^{+}$ions removed from the surface of $\mathrm{Pd}-\mathrm{Au} / \mathrm{SiO}_{2}$ catalysts by primary $\mathrm{Ga}^{+}$ions.

\begin{tabular}{|c|c|c|c|}
\hline Catalyst & Intensity of $\mathrm{Pd}{ }^{*} \cdot 10^{6}$ & Intensity of $\mathrm{Au}_{3} * * \cdot 10^{6}$ & Relative Intensity $\mathrm{Au}_{3} * * / \mathbf{P d} *$ \\
\hline $5 \% \mathrm{Pd}-0.2 \% \mathrm{Au} / \mathrm{SiO}_{2}$ & 1648 & 42 & 0.025 \\
\hline $5 \% \mathrm{Pd}-0.5 \% \mathrm{Au} / \mathrm{SiO}_{2}$ & 1727 & 38 & 0.022 \\
\hline $5 \% \mathrm{Pd}-1 \% \mathrm{Au} / \mathrm{SiO}_{2}$ & 1961 & 128 & 0.065 \\
\hline $5 \% \mathrm{Pd}-2 \% \mathrm{Au} / \mathrm{SiO}_{2}$ & 1984 & 71 & 0.035 \\
\hline $5 \% \mathrm{Pd}-5 \% \mathrm{Au} / \mathrm{SiO}_{2}$ & 2062 & 44 & 0.021 \\
\hline
\end{tabular}

${ }^{*}$ number of ion counts ${ }^{106} \mathrm{Pd}^{+} /$total number of positive ion counts. ${ }^{* *}$ number of ion counts $\mathrm{Au}_{3}{ }^{-} /$total number of negative ion counts.

Additional analysis of the $5 \% \mathrm{Pd}-5 \% \mathrm{Au} / \mathrm{SiO}_{2}$ and $5 \% \mathrm{Pd}-1 \% \mathrm{Au} / \mathrm{SiO}_{2}$ catalysts was performed using XPS to better understand the surface oxidation states of the material (Figures 8 and 9). To analyze the XPS spectra of $5 \% \mathrm{Pd}-5 \% \mathrm{Au} / \mathrm{SiO}_{2}$ and $5 \% \mathrm{Pd}-1 \% \mathrm{Au} / \mathrm{SiO}_{2}$ catalysts, a $-1 \mathrm{eV}$ correction factor was used for the charge compensation associated with the presence of the $\mathrm{SiO}_{2}$ support. This energy shift value was determined by referencing all the energies to the peak positions of the Si $2 p$ core level in the silica support $(103.5 \mathrm{eV})$ and C1s core level in the carbon pad $(285 \mathrm{eV})$.
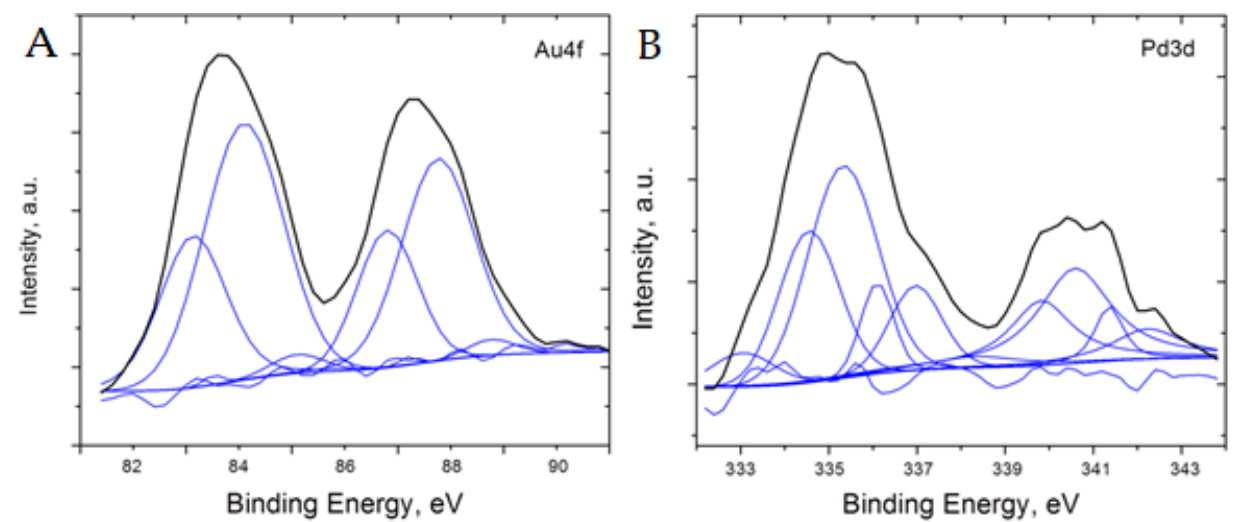

Figure 8. Core level XPS spectra of $\mathrm{Au}(\mathrm{A})$ and $\mathrm{Pd}(\mathbf{B})$ after the charge and background correction for $5 \% \mathrm{Pd}-5 \% \mathrm{Au} / \mathrm{SiO}_{2}$ catalyst.
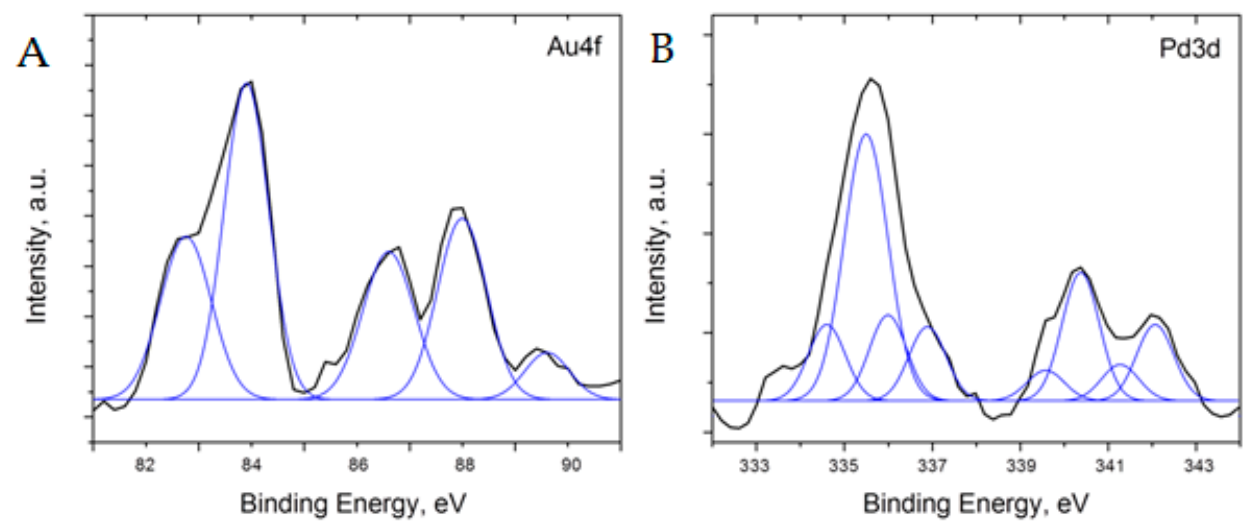

Figure 9. Core level XPS spectra of $\mathrm{Au}(\mathrm{A})$ and $\mathrm{Pd}(\mathbf{B})$ after the charge and background correction for $5 \% \mathrm{Pd}-1 \% \mathrm{Au} / \mathrm{SiO}_{2}$ catalyst. 
The XPS results obtained for both samples of Pd-Au catalyst indicate the presence of metallic palladium and gold, $\mathrm{PdAu}$ alloy, and palladium oxide (Figures 8 and 9, data are shown with $-1 \mathrm{eV}$ charge correction). For the $5 \% \mathrm{Pd}-5 \% \mathrm{Au} / \mathrm{SiO}_{2}$ sample, the peak positions in $\mathrm{Pd} 3 \mathrm{~d}_{5 / 2}$ spectrum can be best fit (with $\pm 0.15 \mathrm{eV}$ precision) at $334.5 \mathrm{eV}$ (Pd-Au alloy), $335.4 \mathrm{eV}$ (metallic $\mathrm{Pd}$ ), $336.1 \mathrm{eV}\left(\mathrm{PdO}_{1-\mathrm{x}}\right.$ ), and $337.0 \mathrm{eV}(\mathrm{PdO})$ [50-55]. On the other hand, the $\mathrm{Pd} 3 \mathrm{~d}_{3 / 2}$ spectrum can be fit with $339.9 \mathrm{eV}$ (PdAu alloy), $340.6 \mathrm{eV}$ (metallic Pd), $341.3 \mathrm{eV}\left(\mathrm{PdO}_{1-\mathrm{x}}\right.$ ), and $342.2 \mathrm{eV}$ (PdO) [53]. The similarity of both parts of Pd3d spectrum indicates that the contribution from Au4d $\mathrm{d}_{5 / 2}$ level at $334.6 \mathrm{eV}$ is very small. The Au4f spectrum has two broad peaks at $83.7 \mathrm{eV}$ and $87.3 \mathrm{eV}$ attributed to $A u 4 f_{7 / 2}$ and $\mathrm{Au} 4 \mathrm{f}_{5 / 2}$, respectively. These apparently wide and asymmetric $A u 4 f_{7 / 2}$ and $A u 4 f_{5 / 2}$ core levels can be fit with the peaks centered at $83.2 \mathrm{eV}$ and $84.1 \mathrm{eV}$ for $\mathrm{Au}_{4 \mathrm{f}}$, , and 96.8 and 87.8 for $\mathrm{Au} 4 \mathrm{f}_{5 / 2}$, respectively. The former value can indicate $\mathrm{PdAu}$ alloy formation, whereas the latter value can be assigned to metallic gold. When comparing the contributions of the individual fits, roughly 50 at $\%$ of $\mathrm{Au}$ and $35 \mathrm{at} \%$ of $\mathrm{Pd}$ are present as $\mathrm{PdAu}$ alloy, whereas 50 at $\%$ of $\mathrm{Pd}$ is metallic and about 15 at $\%$ is a total for $\mathrm{PdO}$ and $\mathrm{PdO}_{1-\mathrm{x}}$. The $\mathrm{Pd} / \mathrm{Au}$ at $\%$ ratio derived from XPS data is 1.8 times lower than the EDS result. This observation indicates that the surface of bimetallic $5 \% \mathrm{Pd}-5 \% \mathrm{Au} / \mathrm{SiO}_{2}$ catalyst may be enriched with gold atoms.

Although the $5 \% \mathrm{Pd}-1 \% \mathrm{Au} / \mathrm{SiO}_{2}$ sample resulted in the XPS spectra with very low intensity (Figure 9), it was possible to fit the Au4f $\mathrm{f}_{7 / 2}$ binding energy spectrum with two peaks at 82.8 and $83.9 \mathrm{eV}$, whereas $\mathrm{Au}_{4} \mathrm{f}_{5 / 2}$ was fit with two peaks at 86.6 and $87.9 \mathrm{eV}$ (spectra are shown after Shirley background subtraction). The results indicate almost the same states of $\mathrm{Au}$, such as in the $5 \% \mathrm{Pd}-5 \% \mathrm{Au} / \mathrm{SiO}_{2}$ sample. A small peak around $90.6 \mathrm{eV}$ originated due to a low signal-to-noise ratio in recorded spectra. Furthermore, the $4 \mathrm{f}_{7 / 2} / 4 \mathrm{f}_{5 / 2}$ ratio in $5 \% \mathrm{Pd}-1 \% \mathrm{Au} / \mathrm{SiO}_{2}$ sample increases, which can indicate a smaller size of Au particles [50]. However, a low signal intensity complicated further analysis. The peak positions in $\mathrm{Pd}_{3} \mathrm{~d}_{5 / 2}$ spectrum for this sample were fit at $334.6 \mathrm{eV}$ (PdAu alloy), $335.5 \mathrm{eV}$ (metallic $\mathrm{Pd}$ ), $336.0 \mathrm{eV}\left(\mathrm{PdO}_{1-\mathrm{x}}\right)$ and $336.9 \mathrm{eV}(\mathrm{PdO})$. Similarly, the $\mathrm{Pd}_{3 / 2}$ spectrum can be fit with $339.6 \mathrm{eV}(\mathrm{PdAu}$ alloy), $340.4 \mathrm{eV}$ (metallic Pd), $341.3 \mathrm{eV}\left(\mathrm{PdO}_{1-\mathrm{x}}\right)$, and $342.1 \mathrm{eV}(\mathrm{PdO})$. A more pronounced peak of metallic Pd is consistent with lower concentration of $\mathrm{Au}$ in supported Pd-Au catalysts [51,52,54,55]. In this sample, roughly $11-14$ at $\%$ of $\mathrm{Pd}$ is in PdAu alloy, $47-53$ at $\%$ of $\mathrm{Pd}$ is metallic, and $42-33 \mathrm{at} \%$ is $\mathrm{PdO} / \mathrm{PdO}_{1-\mathrm{x}}$. The results on the content of metallic $\mathrm{Pd}$ and $\mathrm{PdO}$ in the samples with different $\mathrm{Au}$ concentrations can indicate that gold may promote the reduction of $\mathrm{Pd}$ [53] as well as reduce $\mathrm{Pd}$ re-oxidation upon exposure to atmosphere.

The samples of bimetallic catalysts were also characterized by TPR. Figure 10 presents TPR spectra obtained for $5 \% \mathrm{Pd} / \mathrm{SiO}_{2}, 5 \% \mathrm{Au} / \mathrm{SiO}_{2}$ and for bimetallic systems $5 \% \mathrm{Pd}-0.2 \% \mathrm{Au} / \mathrm{SiO}_{2}, 5 \% \mathrm{Pd}-$ $0.5 \% \mathrm{Au} / \mathrm{SiO}_{2}, 5 \% \mathrm{Pd}-1 \% \mathrm{Au} / \mathrm{SiO}_{2}, 5 \% \mathrm{Pd}-2 \% \mathrm{Au} / \mathrm{SiO}_{2}$, and $5 \% \mathrm{Pd}-5 \% \mathrm{Au} / \mathrm{SiO}_{2}$ after co-impregnation step.

The TPR profile obtained for $5 \% \mathrm{Pd} / \mathrm{SiO}_{2}$ shows two peaks: first, a hydrogen desorption peak with the maximum at $\sim 80^{\circ} \mathrm{C}$, and second, a reduction peak with the maximum $\sim 170^{\circ} \mathrm{C}$. The desorption peaks probably correspond to $\beta$-PdH decomposition, because the $\mathrm{Pd}$ has the ability to form hydride phases under normal conditions. In the TPR profile for $5 \% \mathrm{Pd} / \mathrm{SiO}_{2}$, one main reduction peak appears with a maximum of reduction rate at around $170{ }^{\circ} \mathrm{C}$. This peak could be attributed to the reduction of palladium oxide $(\mathrm{PdO})$ which appearance was associated with the atmospheric exposure of catalysts before TPR analysis.

It was expected that the $\mathrm{PdAu}$ alloy would be more oxidation resistant. In the case of $\mathrm{Pd}-\mathrm{Au} / \mathrm{SiO}{ }_{2}$ catalysts, instead of hydrogen adsorption peaks, we observed desorption peaks only, which is probably connected with $\beta$-PdH decomposition.

In the case of the $\mathrm{Au} / \mathrm{SiO}_{2}$ catalysts the observed peak in the temperature range $200-350{ }^{\circ} \mathrm{C}$ on the TPR profile is related with the reduction of $\mathrm{AuCl}_{3}$ compound according to literature data [43]. This compound did not completely decompose during preparation of the catalytic system due to the low processing temperature during preparation of the system. However, the residual amount of chlorine was below the detection limit in XPS analysis. 


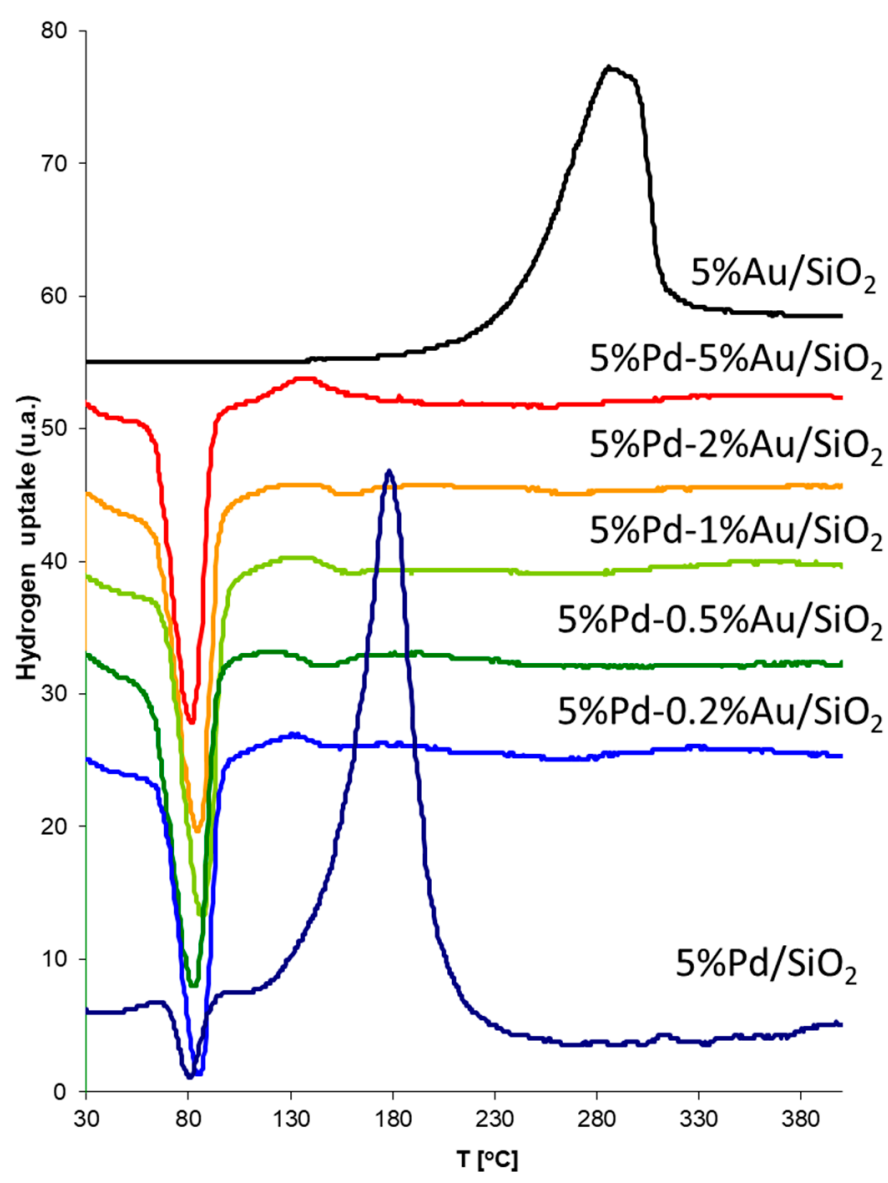

Figure 10. Temperature programmed reduction (TPR) of $\mathrm{Pd}-\mathrm{Au} / \mathrm{SiO}_{2}$ catalysts after co-impregnation step. The catalyst samples $(0.1 \mathrm{~g})$, prior to the TPR measurements were flushed with argon at the room temperature for $0.5 \mathrm{~h}$. TPR runs were performed in the temperature range $25-500{ }^{\circ} \mathrm{C}$, using a mixture of hydrogen-argon ( 5 vol. $\%$ of $\mathrm{H}_{2}$ ) and a linear temperature growth of $20{ }^{\circ} \mathrm{C} / \mathrm{min}$. The flow rate of gases was $30 \mathrm{~cm}^{3} / \mathrm{min}$.

\section{Discussion}

3.1. The Role of Intermetallic Interactions in the Creation of Catalytic Properties of $\mathrm{Pd}-\mathrm{Au} / \mathrm{SiO}_{2}$ Systems in Furfural Reduction in the Water Phase

Addition of a second metal ( $\mathrm{Bi}, \mathrm{Tl}, \mathrm{Sn}, \mathrm{Pb}, \mathrm{Ag})$ to supported palladium systems is the known approach for modification of catalytic properties, especially selectivity in various reactions [56-60]. However, of the origin of the changes of catalytic properties due to such modification is still under discussion. Bimetallic $\mathrm{Pd}-\mathrm{Au} / \mathrm{SiO}_{2}$ catalysts investigated in this work give a good example of successful use of second metal addition. The catalytic performance of prepared $\mathrm{Pd}-\mathrm{Au} / \mathrm{SiO}_{2}$ bimetallic catalysts depends apparently on the $\mathrm{Pd} / \mathrm{Au}$ atomic ratio. The question is what is the possible reason of good activity and high selectivity of $\mathrm{Pd}-\mathrm{Au} / \mathrm{SiO}_{2}$ catalyst in the reduction of furfural into 2-methyloxolan-2-ol in aqueous phase? The effect of gold addition on the catalytic performance of Pd could be described in several different ways:

\subsubsection{Stabilization of Small Metal Particles}

The addition of gold to palladium catalyst facilitates the formation of smaller particles of $\mathrm{Pd}$ and their stabilization under reaction conditions. The XRD, ToF-SIMS, XPS, and SEM-EDS studies of bimetallic $\mathrm{Pd}-\mathrm{Au} / \mathrm{SiO}_{2}$ catalysts reveal the presence of highly dispersed palladium metallic phase on 
the surface of catalysts. Highly dispersed palladium can be responsible for the improved catalytic properties of palladium-gold systems.

On the other hand, only in the case of $5 \% \mathrm{Pd}-1 \% \mathrm{Au} / \mathrm{SiO}_{2}$ catalyst the crystallites of gold smaller than $10 \mathrm{~nm}$ (size of crystallites was estimated on the basis of XRD study), which can be active in furfural reduction, were obtained. In the literature, it was noticed that only Au particles smaller than $10 \mathrm{~nm}$ exhibited interesting catalytic activity [44-46]. The ToF-SIMS and SEM-EDS investigations of prepared Pd-Au catalysts showed, however, that gold was not arranged homogenously on the surface, but it tended to form both relatively small and large crystallites. When the amount of gold incorporated into the $\mathrm{Pd}-\mathrm{Au} / \mathrm{SiO}_{2}$ systems increases, the tendency to form larger crystallites and accumulation gold on the surface were observed.

\subsubsection{Alloy Pd-Au Formation}

XRD and XPS data revealed the presence of solid solutions in the $\mathrm{Pd}-\mathrm{Au} / \mathrm{SiO}_{2}$ systems, whose composition strongly depends on the $\mathrm{Au} / \mathrm{Pd}$ ratio in bimetallic systems. It can be concluded that $\mathrm{Pd}$ atoms substituted $\mathrm{Au}$ atoms in the crystalline lattice of gold. There is some evidence in the literature which shows that the composition of $\mathrm{Pd}-\mathrm{Au}$ alloys has an influence on the catalytic properties in various processes, for example: in direct $\mathrm{H}_{2} \mathrm{O}_{2}$ synthesis [61] or acetoxylation of ethene [62]. Moreover, $\mathrm{Au}$ can preferentially aggregate on the surface in Pd-Au alloy [63,64]; however, some studies showed that Pd-Au clusters can also consist of an Au-rich core which is surrounded by Pd [65].

The catalytic data show that introduction of Au into Pd systems may modify Pd by either an electronic or a geometric effect and improve the selectivity in the reduction of furfural into 2-methyloxolan-2-ol in aqueous phase. Enache et al. [66] suggested that $\mathrm{Au}$ acts as an electronic promoter for $\mathrm{Pd}$ in the reaction of oxidation of primary alcohols to aldehydes and the electronic effect was dominant. On the other hand, Roudgar et al. [67], who used Pd-Au film in synthesis of vinyl acetate, argued that geometric effects are more important than electronic effects in modification of Pd-Au reactivity. In agreement with both these theories are works of Baddeley et al. [68] and Gleich et al. [69], who suggested that the formation of $\mathrm{Pd}_{\mathrm{x}} \mathrm{Au}_{\mathrm{y}}$ surface assemblies plays an essential role in the improvement of catalytic activity.

Furfural is a compound whose adsorption can occur on a different number of surface atoms of metal (e.g., palladium or gold), what can result in the formation of various products. In other words, furfural reduction on palladium supported catalysts appears to be a catalyst structure sensitive reaction. For this reason, surface atoms of catalysts can play an important role in the creating of catalytic properties. So, the formation of solid solution in $\mathrm{Pd}-\mathrm{Au} / \mathrm{SiO}_{2}$ system with various compositions depending on the atomic ratio of $\mathrm{Au} / \mathrm{Pd}$, which, showing different catalytic performance in the studied reaction, may be evidence of certain influence of geometric effects.

\subsection{Products of Reduction of Furfural on $5 \% \mathrm{Pd}-1 \% \mathrm{Au} / \mathrm{SiO}_{2}$ Systems in the Aqueous Phase}

Catalytic hydrogenation is reversible. Hydrogenation of furfural yields products with diversified structures which depend on catalyst, nature of support, reaction conditions and reaction regime, namely batch or continuous flow. In most cases, the dominant products of gas phase hydrogenation are (tetrahydro)furfuryl alcohol and 2-methyl(tetrahydro)furan [70]. A more complex mixture of products is formed under non-homogeneous conditions of hydrogenation proceeding in the liquid phase. Hydrogenation of furfural in aqueous or alcoholic solvents is often accompanied by oxidative dehydrogenation leading to products of hydroxylation or alkoxylation, respectively. Oxidative hydroxylation can be intensive, leading to opening oxolane ring and affording linear products [71-75]. Fourier-transform infrared spectroscopy (FT-IR) measurements and density functional theory (DFT) calculations with $\mathrm{Ni}$ based catalyst revealed that the configuration of adsorbed substrate plays a key role in determining the hydrogenation pathway and selectivity. It has been found that metal doping also leads to different adsorption configurations of the reactants determining intensity of hydrodeoxygenation reaction [76]. The influence of support and dispersion of metal on furfural 
hydrogenation were noticed also for Pd catalysts [77,78]. Silica-supported bimetallic Pd catalyst doped with $\mathrm{Co}$ or $\mathrm{Cu}$ showed enhanced reactivity compared to pure Pd in furfural hydrogenation due to decreased hydrogen surface coverage on catalyst surface of overlayer as compared to pure Pd [79]. Considering the composition of the products formed by hydrogenation of furfural in aqueous phase in the presence of $5 \% \mathrm{Pd}-1 \% \mathrm{Au} / \mathrm{SiO}_{2}$ catalyst (see Table 2), the reaction scheme is proposed in Figure 11. The dominated product formed after 15 min of hydrogenation was furfuryl alcohol (2).

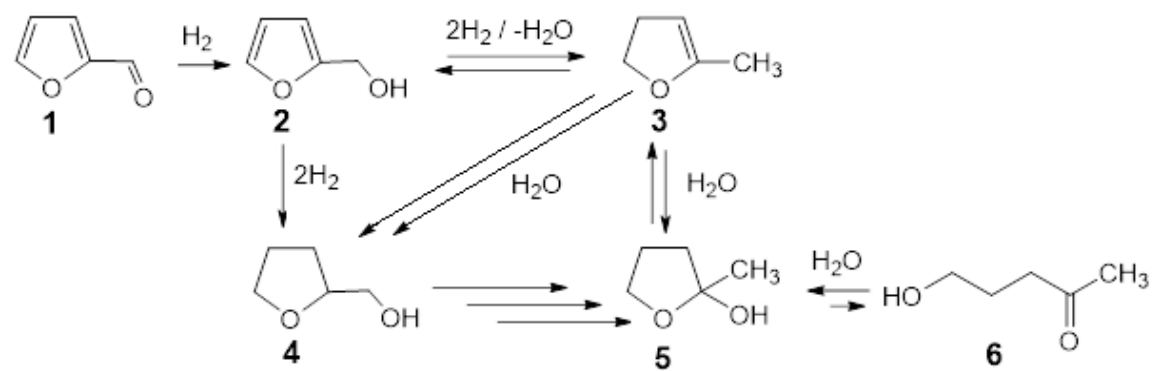

Figure 11. Scheme of the reaction based on the main products of the furfural reduction in the aqueous phase over $5 \% \mathrm{Pd}-1 \% \mathrm{Au} / \mathrm{SiO}_{2}$ catalyst.

Its concentration decreased from $46.2 \%$ to $12.7 \%$ after next $15 \mathrm{~min}$ and then gradually reduced to $0 \%$ after $2 \mathrm{~h}$. The second important intermediate of the preliminary phase of hydrogenation was identified as 2-methyl-4,5-dihydrofurane (3). Its concentration was lowered gradually from $23.2 \%$ after first $15 \mathrm{~min}$ to $0 \%$ after $3 \mathrm{~h}$. The formation of both those compounds was accompanied by a mixture of other products abundant up to $30.6 \%$ after $15 \mathrm{~min}$ and containing the other intermediates required for transformation of 2 into 3 (for example 2-methylfurane, which is suggested in literature data) and 4 , and also gradually reducing to $1.4 \%$ after $4 \mathrm{~h}$. Tetrahydrofurfuryl alcohol (4) was identified after $30 \mathrm{~min}$ and rapidly completely disappeared after $2 \mathrm{~h}$. It can be formed as a result of direct reduction of furfuryl alcohol (2) or by addition of water to 2-methyl-4,5-dihydrofurane (3). The substantial increase of final product 2-methyloxolan-2-ol (5), which is the tautomer of 5-hydroxy-2-pentanone (6), in the presence of intermediate 4 strongly suggests its participation in the reaction pathway. In the pair of tautomers: 5-hydroxy-2-pentanone and 2-methyloxolan-2-ol in aqueous solution, the equilibrium is shifted towards creation of cyclic hemiketal. On the other hand, Mironenko et al. [34,77] during research on the reduction of furfural in water over palladium catalysts supported on carbon materials under slightly severe conditions, identified as the main reaction products: hydroxy-2-pentanone and 4-oxopentanal and 5-hydroxy-2-pentanone, indicating the cyclic form 2-methyloxolan-2-ol as an intermediate product in small amount. These papers stated that the main direction of transformations of furfural over palladium catalysts at any pressure is the hydrolytic opening of the furan ring. Due to insufficient experimental evidence, unambiguous indication of the reaction path of furfural reduction in water is impossible and requires further research.

\section{Materials and Methods}

\subsection{Catalyst Preparation}

A monometallic catalyst containing $5 \mathrm{wt} \%$ palladium was prepared by wet impregnation of $\mathrm{SiO}_{2}$ (Sigma Aldrich, St. Louis, United States, $291 \mathrm{~m}^{2} / \mathrm{g}$ ) with an aqueous solution of $\mathrm{PdCl}_{2}(\mathrm{POCH}$, pure for analysis) acidified to a $\mathrm{pH}$ of about 5 using $\mathrm{HCl}_{\mathrm{aq}}$ (CHEMPUR, 35-38\%, pure for analysis). The preparation was left for $24 \mathrm{~h}$ in an ultrasonic bath with a frequency of $45 \mathrm{kHz}$. Water was evaporated at $60{ }^{\circ} \mathrm{C}$ under vacuum. The $5 \% \mathrm{Pd} / \mathrm{SiO}_{2}$ monometallic catalyst was air dried at $110{ }^{\circ} \mathrm{C}$ for $6 \mathrm{~h}$ and reduced under hydrogen atmosphere $\left(\mathrm{H}_{2}\right.$, Air Products, Premium Plus, Allentown, United States, $99.999 \%, 20 \mathrm{~mL} \cdot \mathrm{min}^{-1}$ ) for $2 \mathrm{~h}$ at $300^{\circ} \mathrm{C}$. A linear temperature rise of $20^{\circ} \mathrm{C} \cdot \mathrm{min}^{-1}$ was set for all stages of thermal processing of this system. In addition, a $5 \% \mathrm{Au} / \mathrm{SiO}_{2}$ (wt\%) monometallic catalyst was 
prepared from the $\mathrm{AuCl}_{3}$ solution ( $\mathrm{POCH}$, Gliwice, Poland, wt. $0.21 \% \mathrm{Au}$ ) according to the procedure described above. In order to determine the catalytic and physicochemical properties of bimetallic systems, $\mathrm{Pd}-\mathrm{Au} / \mathrm{SiO}_{2}$ catalysts containing $5 \mathrm{wt} \% \mathrm{Pd}$ and 0.2 , respectively; $0.5,1,2,5$, and $10 \mathrm{wt} \% \mathrm{Au}$ by the method of co-impregnation of the $\mathrm{SiO}_{2}$ carrier with aqueous solutions of $\mathrm{AuCl}_{3}(\mathrm{POCH}$, pure, $0.21 \% \mathrm{Au}$ ) and $\mathrm{PdCl}_{2}(\mathrm{POCH}$, anhydrous, pure for analysis) were prepared according to the procedure described above. The catalysts have been subjected to AAS, XRD, ToF-SIMS, SEM-EDS, and XPS tests in order to determine their composition and metal interactions, which may affect the activity and selectivity for individual products in furfural reduction.

\subsection{Catalytic Reduction of Furfural}

Hydrogenation of the aqueous furfural solution $(0.1 \mathrm{M}, 25 \mathrm{~mL}$, commercial: $\mathrm{POCH}$, pure or prepared by acidic hydrolysis of brewery's spent grain described below) was performed in a $50 \mathrm{~mL}$ autoclave (Parr Instrument Company, Moline, United States) at $90{ }^{\circ} \mathrm{C}$ and 20 bar hydrogen pressure. A constant amount of catalyst $\left(\mathrm{m}_{\mathrm{cat}}=0.5 \mathrm{~g}\right)$ was weighed for the reaction in each case. The catalyst suspension in liquid reactants was mixed at $500 \mathrm{rpm}$. A further increase in mixing speed no longer resulted in changes in activity, thus ensuring that the reaction proceeded in the kinetic area (diffusion restrictions were eliminated). The autoclave was flushed with argon (Ar, Linde 5.0, $20 \mathrm{~mL} \cdot \mathrm{min}^{-1}$, at $20^{\circ} \mathrm{C}$, for $\left.15 \mathrm{~min}\right)$ to remove air. After $15 \mathrm{~min}$, hydrogen was passed through the autoclave $\left(\mathrm{H}_{2}\right.$, Air Products, Premium Plus, $99.999 \%$, at $20^{\circ} \mathrm{C}$ ) for about $15 \mathrm{~min}$, after which the system was closed and the $\mathrm{H}_{2}$ pressure was raised to $20 \mathrm{bar}$ and the temperature to $90^{\circ} \mathrm{C}$, using a linear temperature rise of $20^{\circ} \mathrm{C} \cdot \mathrm{min}^{-1}$. After reaching the assumed temperature and pressure, the process was carried out for $2 \mathrm{~h}$. Reaction conditions were optimized for mono- and bimetallic palladium catalysts. The qualitative and quantitative composition of the reaction mixture was analyzed using chromatographic techniques (high-performance liquid chromatography (HPLC), gas chromatography with flame ionization detector (GC-FID), and gas chromatography coupled with mass spectrometry (GC-MS)).

Synthesis of Furfural from Brewery's Spent Grain

Furfural was obtained by acidic hydrolysis $\left(\mathrm{H}_{2} \mathrm{SO}_{4}\right.$, analytical grade, $95 \%$, P.P.H. "Stanlab" sp. j., Lublin, Poland; concentration 15\%) of brewery's spent grain. $25 \mathrm{~g}$ of biomass, dried to a constant weight, was weighed and placed in a $1 \mathrm{~L}$ round bottom flask and $250 \mathrm{~mL}$ of mineral acid solution was added. Subsequently, the soaked biomass was heated to boiling and distilled. Condensates collected from the distillation process of the reaction mixture were filtered, neutralized with saturated sodium carbonate solution ( $\mathrm{Na}_{2} \mathrm{CO}_{3}$, analytical grade, $\mathrm{POCH}$, Gliwice, Poland) and analyzed using HPLC (LaChrome, Merck-Hitachi, Darmstadt, Germany, column: Kromasil 100 C18, mobile phase: acetonitrile/phosphate buffer $\left.=5: 95(\mathrm{v} / \mathrm{v}), \mathrm{pH} 4.5, \mathrm{C}_{\text {phosphate }}=0.01, \mathrm{UV}: \lambda=210 \mathrm{~nm}\right)$ to determine the concentration of furfural. Furfural was extracted from the condensates to the organic phase-toluene $\left(\mathrm{C}_{7} \mathrm{H}_{8}\right.$, analytical grade, Chempur, Piekary Ślaskie, Poland). After evaporating the excess toluene, solutions containing above $99 \%$ furfural were obtained which were used in investigations.

\subsection{Catalyst Measurements}

\subsubsection{Powder X-ray Diffraction (XRD)}

XRD experiments were conducted using a PANalytical X'Pert Pro MPD diffractometer equipped with a PANalytical X'Celerator detector (based on Real Time Multiple Strip technology) to obtain room temperature powder $\mathrm{X}$-ray diffraction patterns. The operating parameters for the $\mathrm{X}$-ray source (copper long fine focus $\mathrm{XRD}$ tube) were set to $40 \mathrm{kV}$ voltage and $30 \mathrm{~mA}$ current. The range for data collection was $20-90^{\circ} 2 \theta$ using a step value of $0.0167^{\circ}$ and a dwell time of $20 \mathrm{~s}$. Using the ICDD PDF-2 (version 2004) database as a reference, the crystalline phases were identified. 


\subsubsection{Temperature-Programmed Reduction (TPR)}

The flow apparatus, as described in [80], was used to conduct the TPR measurements in this study. Prior to the TPR measurements, the catalyst samples $(0.1 \mathrm{~g})$ were flushed with argon for $0.5 \mathrm{~h}$ at room temperature. Then, the TPR measurements were conducted with the following set parameters: temperature range of $25-500{ }^{\circ} \mathrm{C}$, hydrogen-argon $\left(5 \mathrm{vol} . \%\right.$ of $\left.\mathrm{H}_{2}\right)$ gas mixture, gas flow rate of $30 \mathrm{~cm}^{3} \cdot \mathrm{min}^{-1}$, and a linear temperature growth of $20^{\circ} \mathrm{C} \cdot \mathrm{min}^{-1}$.

\subsubsection{Secondary Ions Mass Spectrometer Coupled with Time of Flight Detector (ToF-SIMS)}

A ToF-SIMS IV mass spectrometer (Ion-Tof $\mathrm{GmbH}$, Germany, liquid metal ${ }^{69} \mathrm{Ga}^{+}$primary ion gun, high mass resolution time of flight mass analyzer) was used to record secondary ions mass spectra from an estimated $100 \times 100 \mu \mathrm{m}^{2}$ area of the catalyst samples prepared by pressing pellets. Extreme crossover mode or burst alignment mode was used to record the images, giving high lateral resolution. The selected area was irradiated with the following parameters during the measurement: pulses of $25 \mathrm{keV}$ ions, $10 \mathrm{kHz}$ repetition rate, and average ion current $2.5 \mathrm{pA}$. An ion dose below static limit of $1 \times 10^{13}$ ions $\cdot \mathrm{cm}^{2}$ resulted from the analysis time of $50 \mathrm{~s}$. The time of flight (ToF) analyzer counted and separated by mass the secondary ions that were emitted from the bombarded surface. Spectra of the catalyst samples were recorded with high mass resolution $(\mathrm{m} / \Delta \mathrm{m})$ at the $29 \mathrm{~m} . \mathrm{u}$. normally greater than 8000 with the primary ion pulse width of $650 \mathrm{~ns}$.

\subsubsection{Scanning Electron Microscopy with X-ray Microanalysis (SEM-EDS)}

The catalyst powder samples were analyzed using scanning electron microscopy (SEM) (S-4700 scanning electron microscope by HITACHI Ltd, Tokyo, Japan) equipped with energy dispersive spectrometer (EDS) (Thermo Noran Inc., Madison, United States). SEM images, at varying magnifications, were recorded using back-scattered electron (BSE) mode with a YAG detector and accelerating voltage of $25 \mathrm{kV}$. The samples were sputter coated with carbon (Cressington $208 \mathrm{HR}$ system) to reduce electric charging. A series of tests with the same samples was performed using an FEI Quanta 650 SEM equipped with Bruker Energy Dispersive Spectroscopy (EDS) system for chemical microanalysis and to verify the data. The powder catalyst samples were fixed onto sticky, conductive carbon pads with the loose excess powder removed. The data were acquired using the following parameters: $15 \mathrm{kV}$ accelerating voltage, $3.5 \mu \mathrm{A}$ electron beam current, and $10 \mathrm{~mm}$ working distance. The composition of each sample was measured from an area of approximately $0.25 \mathrm{~mm}^{2}$ and repeated three times utilizing different locations on each sample.

\subsubsection{X-ray Photoelectron Spectroscopy XPS}

The chemical bonding nature at the surface of selected $\mathrm{Pd}-\mathrm{Au} / \mathrm{SiO}_{2}$ catalysts was determined by X-ray photoelectron spectroscopy (XPS). Samples were prepared by pressing the catalytic powders onto high purity carbon filled acrylic adhesive tabs (PELCO Tabs ${ }^{\mathrm{TM}}$ Carbon Conductive Tabs) with very small impurities of $\mathrm{Al}$ and $\mathrm{Si}$, and they were utilized in spectra calibration. The samples were placed into a VersaProbe 5000 (Ulvac-PHI Inc., Chigasaki, Japan) spectrometer. Survey and high-resolution spectra were taken with a focused, monochromatic $\mathrm{Al} \mathrm{K}-\alpha$ source $(\mathrm{E}=1486.6 \mathrm{eV} ; 100 \mu \mathrm{m}$ spot diameter). A cold cathode electron flood gun and low-energy $\mathrm{Ar}^{+}$ion-beam source provided induced charge compensation. The operating pressure was $2 \cdot 10^{-6} \mathrm{~Pa}$ for Ar gas and the system base pressure was $5 \cdot 10^{-8} \mathrm{~Pa}$. To avoid ion-induced surface damage, surface sputtering was not used.

The XPS results for the catalyst samples were fitted with proprietary software (Multipak) and compared to both the NIST database (NIST Standard Reference Database 20, Version 3.5) and prior published data. 


\subsubsection{Atomic Absorption Spectrometry (AAS)}

The chemical composition of bimetallic $\mathrm{Pd}-\mathrm{Au} / \mathrm{SiO}_{2}$ catalysts was determined by the AAS method using SOLAAR M6 spectrometer (Unicam Instruments Ltd., Cambridge, England). Firstly, $0.1 \mathrm{~g}$ of catalysts were mineralized using MLS-1200 Mega Microwave Digestion System (Milestone S.r.l., Bergamo, Italy). Mixture of nitric (V), hydrochloric and hydrofluoric acids was used for mineralization of catalysts samples. Contents of $\mathrm{Pd}$ and $\mathrm{Au}$ in catalysts were determined at analytical wavelengths $247.6 \mathrm{~nm}$ and $242.8 \mathrm{~nm}$ respectively, with atomization in acetylene/air flame (Table 5).

Table 5. The content of $\mathrm{Pd}$ and $\mathrm{Au}$ in $5 \% \mathrm{Pd}-\mathrm{X} \% \mathrm{Au} / \mathrm{SiO}_{2}$ catalysts determined by the AAS technique.

\begin{tabular}{|c|c|c|c|c|c|c|}
\hline \multicolumn{2}{|c|}{ Metal/Catalyst } & \multirow{2}{*}{$\frac{\mathbf{P d} / \mathrm{SiO}_{\mathbf{2}}}{51034}$} & \multirow{2}{*}{$\frac{\mathbf{5} \% \mathbf{P d}-\mathbf{0 . 5} \% \mathbf{A u} / \mathbf{S i O}_{\mathbf{2}}}{48329}$} & \multirow{2}{*}{$\frac{\mathbf{5 \%} \mathbf{P d}-\mathbf{1} \% \mathbf{A u} / \mathrm{SiO}_{\mathbf{2}}}{50414}$} & \multicolumn{2}{|c|}{$5 \% \mathrm{Pd}-2 \% \mathrm{Au} / \mathrm{SiO}_{2} 5 \% \mathrm{Pd}-5 \% \mathrm{Au} / \mathrm{SiO}_{2}$} \\
\hline \multirow{2}{*}{$\mathrm{Pd}$} & {$[\mathrm{mg} / \mathrm{kg}]$} & & & & 48762 & 49237 \\
\hline & $\%[w / w]$ & 5.1 & 4.8 & 5.0 & 4.9 & 4.9 \\
\hline \multirow{2}{*}{$\mathrm{Au}$} & {$[\mathrm{mg} / \mathrm{kg}]$} & - & 4298 & 9753 & 18630 & 45875 \\
\hline & $\%[w / w]$ & - & 0.4 & 1.0 & 1.9 & 4.6 \\
\hline $\mathrm{Pd} / \mathrm{Au}$ & {$[\mathrm{mol} / \mathrm{mol}]$} & - & 20.9 & 9.6 & 4.8 & 2.0 \\
\hline
\end{tabular}

\section{Conclusions}

Silica supported palladium-gold highly dispersed catalysts showed composition dependent high activity and selectivity in the reduction reaction of furfural into valuable fuel additives (furfuryl alcohol, 2-methyl-4,5-dihydrofuran, tetrahydrofurfuryl alcohol, 2-methyloxolan-2-ol) under mild conditions in water.

After activation of $\mathrm{Pd}-\mathrm{Au} / \mathrm{SiO}_{2}$ catalysts in hydrogen atmosphere at the temperature $300{ }^{\circ} \mathrm{C}$, interactions between both metal components of an active phase led to the formation of possibly Au-rich and Pd-rich solid solutions with different crystallite sizes. The compositions and particle size of those solid solutions strongly depend on the $\mathrm{Au} / \mathrm{Pd}$ ratio in bimetallic systems. Due to those interactions, the character and binding energy between the adsorbed particles (furfural and hydrogen), and metal being the active center can undergo changes, which consequently leads to the changes of selectivity of the whole system.

Very good catalytic properties of system $5 \% \mathrm{Pd}-1 \% \mathrm{Au} / \mathrm{SiO}_{2}$ in the reaction of water phase furfural hydrogenation into 2-methyloxolan-2-ol under mild conditions indicate the possibility of their commercial application (patent application P. 431048: "A method of producing a mixture of liquid fuel additives from furfural and a method of producing palladium-gold catalysts used in this process", authors: M. Binczarski, Z. Kaminski, S. Karski, B. Kolesinska, M. Modelska, I. Witonska, application at the Patent Office of Poland on 5 September 2019).

Supplementary Materials: The following are available online at http://www.mdpi.com/2073-4344/10/4/444/s1, Figure S1: 1H-NMR spectrum of the sample of reaction mixture extracted to chloroform after 120 min hydrogenation of furfural in water over 5\%Pd-1\%Au/SiO2 catalyst.(Obtained on Bruker Spektrometer AVANCE DPX $250 \mathrm{MHz}$ ), Figure S2. 13C-NMR spectrum of the sample of reaction mixture extracted to chloroform after $120 \mathrm{~min}$ hydrogenation of furfural in water over $5 \% \mathrm{Pd}-1 \% \mathrm{Au} / \mathrm{SiO} 2$ catalyst.(Obtained on Bruker Spektrometer AVANCE DPX $250 \mathrm{MHz}$ ), Table S1: GC-MS analysis of reaction products, Table S2. Mass spectra of products with retention times 21.5(6) and 21.8(2) in the reduction of furfural in water phase over 5\%Pd-1\%Au/SiO2 catalyst (after $240 \mathrm{~min}$ of reaction run).

Author Contributions: Conceptualization, I.A.W. and A.S.; methodology, I.A.W. and A.S.; validation, M.M., M.J.B. and C.J.S.; formal analysis, I.A.W. and A.S.; investigation, M.M., M.J.B., B.K., C.J.S., P.M.; writing-original draft preparation, I.A.W., M.M., M.J.B., P.M. and S.K.; writing-review and editing, I.A.W., A.S. and Z.K.; visualization, M.M. and M.J.B.; project administration, I.A.W. and C.J.S. All authors have read and agreed to the published version of the manuscript.

Funding: This research was funded by The National Centre for Research and Development under Project BIOSTRATEG2/296369/5/NCBR/2016. One of the co-authors (CJS) was supported by the National Science Foundation (U.S) International Research Experience for Students Program under Grant \#1558268.

Conflicts of Interest: The authors declare no conflict of interest. 


\section{References}

1. Luo, Y.; Li, Z.; Li, X.; Liu, X.; Fan, J.; Clark, J.H.; Hu, C. The production of furfural directly from hemicellulose in lignocellulosic biomass: A review. Catal. Today 2019, 319, 14-24. [CrossRef]

2. Bizzi, C.A.; Santos, D.; Sieben, T.C.; Motta, G.V.; Mello, P.A.; Flores, E.M.M. Furfural production from lignocellulosic biomass by ultrasound-assisted acid hydrolysis. Ultrason. Sonochem. 2019, 51, 332-339. [CrossRef]

3. Yan, K.; Wu, G.; Lafleur, T.; Jarvis, C. Production, properties and catalytic hydrogenation of furfural to fuel additives and value-added chemicals. Renew. Sustain. Energy. Rev. 2014, 38, 663-676. [CrossRef]

4. da Costa Lopes, A.M.; Morais, A.R.C.; Łukasik, R.M. Sustainable Catalytic Strategies for C5-Sugars and Biomass Hemicellulose Conversion Towards Furfural Production. In Production of Platform Chemicals from Sustainable Resources. Biofuels and Biorefineries; Fang, Z., Smith, R., Jr., Qi, X., Eds.; Springer: Singapore, 2017. [CrossRef]

5. Delbecq, F.; Wang, Y.; Muralidhara, A.; Ouardi, K.E.I.; Marlair, G.; Len, C. Hydrolysis of Hemicellulose and Derivatives-A Review of Recent Advances in the Production of Furfura. Front. Chem. 2018, 6, 146. [CrossRef]

6. Steinbach, D.; Kruse, A.; Sauer, J. Pretreatment technologies of lignocellulosic biomass in water in view of furfural and 5-hydroxymethylfurfural production-A review. Biomass Convers. Biorefinery 2017, 7, $247-274$. [CrossRef]

7. Nimlos, M.R.; Qian, X.; Davis, M. Energetics of xylose decomposition as determined using quantum mechanics modeling. J. Phys. Chem. A 2006, 110, 11824-11838. [CrossRef]

8. Jia, Q.; Teng, X.; Yu, S.; Si, Z.; Li, G.; Zhou, M.; Cai, D.; Qin, P.; Chen, B. Production of furfural from xylose and hemicelluloses using tin-loaded sulfonated diatomite as solid acid catalyst in biphasic system. Bioresour. Technol. Rep. 2019, 6, 145-151. [CrossRef]

9. Antal, M.J., Jr.; Leesomboon, T.; Mok, W.S. Mechanism of formation of 2-furaldehyde from D-xylose. Carbohydr. Res. 1991, 217, 71-85. [CrossRef]

10. Malinowski, A.; Wardzińska, D. Katalityczna konwersja furfuralu do biokomponentów paliwowych. CHEMIK 2012, 66, 982-990.

11. Michalska, K.; Ledakowicz, S. Degradacja struktur lignocelulozowych oraz produktów ich hydrolizy. Inż. Apar. Chem. 2012, 51, 157-159.

12. O'Neill, R.; Ahmad, M.N.; Vanoye, L.; Aiouache, F. Kinetics of aqueous phase dehydration of xylose into furfural catalyzed byZSM-5 zeolite. Ind. Eng. Chem. Res. 2009, 48, 4300-4306. [CrossRef]

13. Ferreira, L.R.; Lima, S.; Neves, P.; Antunes, M.M.; Rocha, S.M.; Pillinger, M.; Portugal, I.; Valente, A.A. Aqueous phase reactions of pentoses in the presence of nanocrystalline zeolite beta: Identification of by-products and kinetic modelling. Chem. Eng. J. 2013, 215-216, 772-783. [CrossRef]

14. Dias, A.S.; Pillinger, M.; Valente, A.A. Dehydration of xylose into furfural over micro-mesoporous sulfonic acid catalysts. J. Catal. 2005, 229, 414-423. [CrossRef]

15. Dias, A.S.; Lima, S.; Pillinger, M.; Valente, A.A. Modified versions of sulfated zirconia as catalysts for the conversion of xylose to furfural. Catal. Lett. 2007, 114, 151-160. [CrossRef]

16. Zhang, J.; Zhuang, J.; Lin, L.; Liu, S.; Zhang, Z. Conversion of D-xylose into furfural with mesoporous molecular sieve MCM-41 as catalyst and butanol as the extraction phase. Biomass Bioenergy 2012, 39, 73-77. [CrossRef]

17. Zhang, L.; Yu, H. Conversion of xylan and xylose into furfural in biorenewable deep eutectic solvent with trivalent metal chloride added. Biol. Res. 2013, 8, 6014-6025. [CrossRef]

18. Dziugan, P.; Binczarski, M.; Modelska, M.; Witonska, I.; Sadowski, A. Recovery of municipal green bio-waste by the way of chemical transformation into valuable chemical products: Intermediates of bio-polymers, green solvents and bio-components of fuels. Logistyka Odzysku 2015, 3, 87-89.

19. Mariscal, R.; Maireles-Torres, P.; Ojeda, M.; Sádaba, I.; López Granados, M. Furfural: A renewable and versatile platform molecule for synthesis of chemicals and fuels. Energy Environ. Sci. 2016, 9, 1144-1189. [CrossRef]

20. Haan, R.J.; Lange, J. Gasoline Composition and Process for the Preparation of Alkylfurfuryl Ether. U.S. Patent 20110035991 A1, 17 February 2011. 
21. Van Buijtenen, J.; Lange, J.P.; Price, R.J. Process for Preparing a Hydrocarbon or Mixture of hHydrocarbons. U.S. Patent 2011/0173877, 21 July 2011.

22. Graves, G.D. Reduction of Furfural to Tetrahydrofurfuryl Alcohol. U.S. Patent 1794453, 3 March 1931.

23. Priickner, H. Process for Producing Tetrahydrofurfuryl Alcohol. U.S. Patent 2071704, 23 February 1937.

24. Merat, N.; Godawa, C.; Gaset, A. High selective production of tetrahydrofurfuryl alcohol: Catalytic hydrogenation of furfural and furfuryl alcohol. J. Chem. Technol. Biotechnol. 1990, 48, 145-159. [CrossRef]

25. Chen, X.; Sun, W.; Xiao, N.; Yan, Y.; Liu, S. Experimental study for liquid phase selective hydrogenation of furfuryl alcohol to tetrahydrofurfuryl alcohol on supported Ni catalysts. Chem. Eng. J. 2007, 126, 5-11. [CrossRef]

26. Modelska, M.; Berlowska, J.; Kregiel, D.; Cieciura, W.; Antolak, H.; Tomaszewska, J.; Binczarski, M.; Szubiakiewicz, E.; Witonska, I.A. Concept for recycling waste biomass from the sugar industry for chemical and biotechnological purposes. Molecules 2017, 22, 1544. [CrossRef] [PubMed]

27. Wilson, H.B. Process for Hydrogenation of Furfural. U.S. Patent 2487054, 8 November 1949.

28. Lesiak, M.; Binczarski, M.; Karski, S.; Maniukiewicz, W.; Rogowski, J.; Szubiakiewicz, E.; Berlowska, J.; Dziugan, P.; Witonska, I. Hydrogenation of furfural over $\mathrm{Pd}-\mathrm{Cu} / \mathrm{Al}_{2} \mathrm{O}_{3}$ catalysts. The role of interaction between palladium and copper on determining catalytic properties. J. Mol. Catal. A Chem. 2014, 395, 337-348. [CrossRef]

29. Hronec, M.; Fulajtarova, K.; Liptaj, T. Effect of catalyst and solvent on the furan ring rearrangement to cyclopentanone. Appl. Catal. A 2012, 437, 104-111. [CrossRef]

30. Zhang, B.; Zhu, Y.; Ding, G.; Zheng, H.; Li, Y. Selective conversion of furfuryl alcohol to 1,2-pentanediol over a $\mathrm{Ru} / \mathrm{MnO}_{\mathrm{x}}$ catalyst in aqueous phase. Green Chem. 2012, 14, 3402-3409. [CrossRef]

31. Rogowski, J.; Andrzejczuk, M.; Berłowska, J.; Binczarski, M.; Kregiel, D.; Kubiak, A.; Modelska, M.; Szubiakiewicz, E.; Stanishevsky, A.; Tomaszewska, J.; et al. WxC- $\beta$-SiC nanocomposite catalysts used in aqueous phase hydrogenation of furfural. Molecules 2017, 22, 2033. [CrossRef] [PubMed]

32. Chen, B.; Li, F.; Huang, Z.; Yuan, G. Tuning catalytic selectivity of liquid-phase hydrogenation of furfural via synergistic effects of supported bimetallic catalysts. Appl. Catal. A 2015, 500, 23-29. [CrossRef]

33. Kamiyama, M.; Horiuchi, M.; Umano, K.; Kondo, K.; Otsuka, Y.; Shibamoto, T. Antioxidant/Antilnflammatory Activities and Chemical Composition of Extracts from the Mushroom Trametes Versicolor. Int. J. Nutr. Food Sci. 2013, 2, 85-91. [CrossRef]

34. Mironenko, R.M.; Belskaya, O.B. Effect of the conditions for the aqueous-phase hydrogenation of furfural over Pd/C catalysts on the reaction routes. AIP Conf. Proc. 2019, 2141, 020010. [CrossRef]

35. Fulajtárova, K.; Soták, T.; Hronec, M.; Váavra, I.; Dobročka, E.; Omastová, M. Aqueous phase-hydrogenation of furfural to furfuryl alcohol over Pd-Cu catalysts. Appl. Catal. A 2015, 502, 78-85. [CrossRef]

36. Liu, S.; Amada, Y.; Tamura, M.; Nakagawa, Y.; Tomishige, K. One-pot selective conversion of furfural into 1,5-pentanediol over a Pd-added $\mathrm{Ir}-\mathrm{ReO}_{\mathrm{x}} / \mathrm{SiO}_{2}$ bifunctional catalyst. Green Chem. 2014, 16, 617-626. [CrossRef]

37. Biradar, N.S.; Hengne, A.M.; Birajdar, S.N.; Niphadkar, P.S.; Joshi, P.N.; Rode, C.V. Single-pot formation of THFAL via catalytic hydrogenation of FFR over Pd/MFI catalyst. ACS Sustain. Chem. Eng. 2014, 2, $272-281$. [CrossRef]

38. Nakagawa, Y.; Tomishige, K. Total hydrogenation of furan derivatives over silica-supported Ni-Pd alloy catalyst. Catal. Commun. 2010, 12, 154-156. [CrossRef]

39. Date, N.S.; Parola, V.L.; Rode, C.V.; Testa, M.L. Ti-Doped Pd-Au catalysts for One-Pot hydrogenation and ring opening of furfural. Catalysts 2018, 8, 252. [CrossRef]

40. Aldosari, O.F. Selective conversion of furfuryl alcohol to 2-methylfuran over nanosilica supported Au:Pd bimetallic catalysts at room temperature. J. Saudi Chem. Soc. 2019, 23, 938-946. [CrossRef]

41. Szubiakiewicz, E.; Modelska, M.; Brzezinska, M.; Binczarski, M.J.; Severino, C.J.; Stanishevsky, A.; Witonska, I.A. Influence of modification of supported palladium systems by polymers: PVP, AMPS and AcrAMPS on their catalytic properties in the reaction of transformation of biomass into fuel bio-components. Fuel 2020, 271, 117584. [CrossRef]

42. Edwards, J.K.; Thomas, A.; Solsona, B.E.; Landon, P.; Carley, A.F.; Hutchings, G.J. Comparison of supports for the direct synthesis of hydrogen peroxide from $\mathrm{H}_{2}$ and $\mathrm{O}_{2}$ using $\mathrm{Au}-\mathrm{Pd}$ catalysts. Catal. Today 2007, 122, 397-402. [CrossRef] 
43. Han, Y.-F.; Wang, J.-H.; Kumar, D.; Yan, Z.; Goodman, D.W. A kinetic study of vinyl acetate synthesis over Pd-based catalysts: Kinetics of vinyl acetate synthesis over $\mathrm{Pd}-\mathrm{Au} / \mathrm{SiO}_{2}$ and $\mathrm{Pd} / \mathrm{SiO}_{2}$ catalysts. J. Catal. 2005, 232, 467-475. [CrossRef]

44. Haruta, M. Size- and support-dependency in the catalysis of gold. Catal. Today 1997, 36, 153-166. [CrossRef]

45. Haruta, M.; Daté, M. Advances in the catalysis of Au nanoparticles. Appl. Catal. A Gen. 2001, 222, 427-437. [CrossRef]

46. Mierczynski, P.; Vasilev, K.; Mierczynska, A.; Maniukiewicz, W.; Szynkowska, M.I.; Maniecki, T.P. Bimetallic $\mathrm{Au}-\mathrm{Cu}, \mathrm{Au}-\mathrm{Ni}$ catalysts supported on MWCNTs for oxy-steam reforming of methanol. Appl. Catal. B Environ. 2016, 185, 281-294. [CrossRef]

47. Baatz, C.; Thieleckie, N.; Prüsse, U. Influence of the preparation conditions on the properties of gold catalysts for the oxidation of glucose. Appl. Catal. B Environ. 2007, 70, 653-660. [CrossRef]

48. Baatz, C.; Prüsse, U. Preparation of gold catalysts for glucose oxidation by incipient wetness. J. Catal. 2007, 249, 34-40. [CrossRef]

49. Thielecke, N.; Vorlop, K.D.; Prüsse, U. Long-term stability of an $\mathrm{Au} / \mathrm{Al}_{2} \mathrm{O}_{3}$ catalyst prepared by incipient wetness in continuous-flow glucose oxidation. Catal. Today 2007, 122, 266-269. [CrossRef]

50. Chenakin, S.P.; Kruse, N. Au 4 f spin-orbit coupling effects in supported gold nanoparticles. Phys. Chem. Chem. Phys. 2016, 33, 22778-22782. [CrossRef] [PubMed]

51. Venezia, A.M.; La Parola, V.; Pawelec, B.; Fierro, J.L.G. Hydrogenation of aromatics over $\mathrm{Au}-\mathrm{Pd} / \mathrm{SiO}_{2}-\mathrm{Al}_{2} \mathrm{O}_{3}$ catalysts; Support acidity effect. Appl. Catal. A Gen. 2004, 264, 43-51. [CrossRef]

52. Venezia, A.M.; Liotta, L.F.; Pantaleo, G.; La Parola, V.; Deganello, G.; Beck, A.; Koppány, Z.; Frey, K.; Horváth, D.; Guczi, L. Activity of $\mathrm{SiO} 2$ supported gold-palladium catalysts in CO oxidation. Appl. Catal. A Gen. 2003, 251, 359-368. [CrossRef]

53. Qian, K.; Huang, W. Au-Pd alloying-promoted thermal decomposition of PdO supported on $\mathrm{SiO}_{2}$ and its effect on the catalytic performance in CO oxidation. Catal. Today 2011, 164, 320-324. [CrossRef]

54. Nutt, M.O.; Heck, K.N.; Alvarez, P.; Wong, M.S. Improved Pd-on-Au bimetallic nanoparticle catalysts for aqueous-phase trichloroethene hydrodechlorination. Appl. Catal. B Environ. 2006, 69, 115-125. [CrossRef]

55. Liu, C.; Cai, X.; Wang, J.; Liu, J.; Riese, A.; Chen, Z.; Sun, X.; Wang, S.-D. One-step synthesis of AuPd alloy nanoparticles on graphene as a stable catalyst for ethanol electro-oxidation. Int. J. Hydrogen Energy 2016, 41, 13476-13484. [CrossRef]

56. Karski, S.; Witońska, I. Bismuth as an additive modifying the selectivity of palladium catalysts. J. Mol. Catal. A Chem. 2003, 191, 87-92. [CrossRef]

57. Karski, S.; Witońska, I.; Gołuchowska, J. Catalytic properties of $\mathrm{Pd}-\mathrm{Tl} / \mathrm{SiO}_{2}$ systems in the reaction of liquid phase oxidation of aldoses. J. Mol. Catal. A Chem. 2006, 245, 225-230. [CrossRef]

58. Karski, S. Activity and selectivity of $\mathrm{Pd}-\mathrm{Bi} / \mathrm{SiO}_{2}$ catalysts in the light of mutual interaction between $\mathrm{Pd}$ and Bi. J. Mol. Catal. A Chem. 2006, 253, 147-154. [CrossRef]

59. Wenkin, M.; Ruiz, P.; Delmon, B.; Devillers, M. The role of bismuth as promoter in Pd-Bi catalysts for the selective oxidation of glucose to gluconate. J. Mol. Catal. A Chem. 2002, 180, 141-159. [CrossRef]

60. Karski, S.; Witońska, I.; Rogowski, J.; Gołuchowska, J. Interaction between Pd and Ag on the surface of silica. J. Mol. Catal. A Chem. 2005, 240, 155-163. [CrossRef]

61. Hutchings, G.J. Nanocrystalline gold and gold palladium alloy catalysts for chemical synthesis. Chem. Commun. 2008, 10, 1148-1164. [CrossRef]

62. Chen, M.; Kumar, D.; Yi, C.-W.; Goodman, D.W. The promotional effect of gold in catalysis by palladium-gold. Science 2005, 310, 291-293. [CrossRef]

63. Han, Y.-F.; Kumar, D.; Goodman, D.W. Particle size effects in vinyl acetate synthesis over Pd/SiO 2 . J. Catal. 2005, 230, 353-358. [CrossRef]

64. Maire, G.; Hilarie, L.; Legare, P.; Gault, F.G.; O'Cinneide, A. Auger electron spectroscopy study of chemisorption-induced segregation in a Pd-Au alloy. J. Catal. 1976, 44, 293-299. [CrossRef]

65. Reifsnyder, S.N.; Lamb, H.H. Characterization of silica-supported Pd-Au clusters by x-ray absorption spectroscopy. J. Phys. Chem. B 1999, 103, 321-329. [CrossRef]

66. Enache, D.I.; Edwards, J.K.; Landon, P.; Solsona-Espiru, B.; Carley, A.F.; Herzing, A.A.; Watanabe, M.; Kiely, C.J.; Knight, D.W.; Hutchings, G.J. Solvent-free oxidation of primary alcohols to aldehydes using $\mathrm{Au}-\mathrm{Pd} / \mathrm{TiO}_{2}$ catalysts. Science 2006, 311, 362-365. [CrossRef] 
67. Roudgar, A.; Gro $\beta$, A. Local reactivity of metal overlayers: Density functional theory calculations of Pd on Au. Phys. Rev. B 2003, 67, 033409. [CrossRef]

68. Baddeley, C.J.; Ormerod, R.M.; Stephenson, A.W.; Lambert, R.M. Surface structure and reactivity in the cyclization of acetylene to benzene with Pd overlayers and Pd/Au Surface Alloys on Au\{111\}. J. Phys. Chem. 1995, 99, 5146-5151. [CrossRef]

69. Gleich, B.; Ruff, M.; Behm, R.J. Correlation between local substrate structure and local chemical properties: CO adsorption on well-defined bimetallic AuPd(111) surfaces. Surf. Sci. 1997, 386, 48-55. [CrossRef]

70. Wang, Y.; Zhao, D.; Rodríguez-Padrón, D.; Len, C. Recent advances in catalytic hydrogenation of furfural. Catalysts 2019, 9, 796. [CrossRef]

71. Schniepp, L.E.; Geller, H.H.; Von Korff, R.W.; Von Korff, R.W. The Preparation of Acetopropyl Alcohol and 1,4-Pentanediol from Methylfuran. J. Am. Chem. Soc. 1947, 69, 672-674. [CrossRef]

72. Dibble, T.S. Cyclization of 1,4-hydroxycarbonyls is not a homogenous gas phase process. Chem. Phys. Lett. 2007, 447, 5-9. [CrossRef]

73. Rodiansono; Dewi Astuti, M.; Hara, T.; Ichikuni, N.; Shimazu, S. One-pot selective conversion of C5-furan into 1,4-pentanediol over bulk Ni-Sn alloy catalysts in an ethanol/ $\mathrm{H}_{2} \mathrm{O}$ solvent mixture. Green Chem. 2019, 21, 2307-2315. [CrossRef]

74. Hu, X.; Westerhof, R.J.M.; Wu, L.; Dong, D.; Li, C.Z. Upgrading biomass-derived furans via acid-catalysis/hydrogenation: The remarkable difference between water and methanol as the solvent. Green Chem. 2015, 17, 219-224. [CrossRef]

75. Liang, X.; Haynes, B.S.; Montoya, A. Acid-Catalyzed ring opening of furan in aqueous solution. Energy Fuels 2018, 32, 4139-4148. [CrossRef]

76. Ren, G.; Wang, G.; Mei, H.; Xu, Y.; Huang, L. A theoretical insight into furfural conversion catalyzed on the Ni(111) surface. Phys. Chem. Chem. Phys. 2019, 21, 23685-23696. [CrossRef]

77. Mironenko, R.M.; Talsi, V.P.; Gulyaeva, T.I.; Trenikhin, M.V.; Belskaya, O.B. Aqueous-phase hydrogenation of furfural over supported palladium catalysts: Effect of the support on the reaction routes. React. Kinet. Mech. Catal. 2019, 126, 811-827. [CrossRef]

78. Lee, J.; Woo, J.; Nguyen-Huy, C.; Lee, M.S.; Joo, S.H.; An, K. Highly dispersed Pd catalysts supported on various carbons for furfural hydrogenation. Catal. Today 2019. [CrossRef]

79. Liu, P.; Qiu, W.; Zhang, C.; Tan, Q.; Zhang, C.; Zhang, W.; Song, Y.; Wang, H.; Li, C. Kinetics of furfural hydrogenation over bimetallic overlayer catalysts and the effect of oxygen vacancy concentration on product selectivity. ChemCatChem 2019, 11, 3296-3306. [CrossRef]

80. Paryjczak, T.; Rynkowski, J.; Karski, S. Thermoprogrammed reduction of cobalt oxide catalysts. J. Chromatogr. 1980, 188, 254-256. [CrossRef]

(C) 2020 by the authors. Licensee MDPI, Basel, Switzerland. This article is an open access article distributed under the terms and conditions of the Creative Commons Attribution (CC BY) license (http://creativecommons.org/licenses/by/4.0/). 